\title{
Towards a Theory of Marketing Systems as the Public Good
}

\author{
Djavlonbek Kadirov'®
}

\begin{abstract}
The Marketing-Systems-as-the-Public-Good framework proposed in this article outlines the general principles of interpreting change in marketing systems. The framework advances a view of purposeful temporal change based on collective practices that a) identify, develop and maintain key common resources; b) initiate public-private asset transitions; c) facilitate contributory participation of market actors in marketing system processes; and d) perpetuate attenuating mechanisms. These processes construct the system as the public good with non-excludable and non-subtractable (dis)benefits. The drive for further change arises when the system's overarching structures infuse value creation practices with macromotive-based meaningfulness (e.g. the justice motive) which differentially resonates in market actors' lived experiences, who through ongoing localized sociopolitical discourses and contestation undertake to correct perceived justice digressions. The case of the historical evolution of the Uzbek Bozor Marketing System illustrates the key elements of the proposed framework.
\end{abstract}

\section{Keywords}

marketing systems, macromotive, the justice motive, public good, market inclusiveness, public-private good transition, contributory participation, marketing-system governance, market design, attenuating mechanisms

Are marketing systems an emergent outcome of microbehavioral activities or the result of deliberate change processes? Can marketing systems actually be "purpose-driven", as Sheth (1992) has proposed? How and when does a need for change in marketing systems arise?

This study will focus on the body of macromarketing knowledge related to the formation, development and evolution of marketing systems (Fisk 1967, 1997; Kadirov and Varey 2011; Layton 2007, 2009, 2015; Layton and Duffy 2017; Mittelstaedt, Kilbourne, and Mittelstaedt 2006). Recently, Layton's $(2007,2009,2015)$ research on marketing systems clarified multiple processes that drive marketing system emergence and evolution. Yet, a number of central questions remain unanswered. Layton asks,

Could a desire for a change in a social system be the starting point for the design and construction of a marketing system where the social change was a direct consequence, not a byproduct? How could an evolutionary dynamic be introduced and allowed to develop into a complex, multi-level system? (Layton 2017, p. 48)

The topic of change in marketing systems is not sufficiently studied in macromarketing. Much effort in the field is devoted to investigating marketing systems with something of a "snapshot" focus (Kadirov and Varey 2011; Layton 2007, 2015; Mittelstaedt, Kilbourne, and Mittelstaedt 2006); thus, there is dearth of work on temporal processes (Layton 2017). This article is a preliminary step in exploring, temporal, ongoing change in marketing systems and understanding the antecedents and catalysts for change. It introduces the Marketing Systems-as-a-Public-Good framework that broadly outlines one of the possible interpretations of purpose-driven change in marketing systems. This framework posits that marketing systems represent "action fields" with public good characteristics, continually reduced from complexity, in order to maintain the meaningfulness of both collective and individual action, the view of environment, and desired outcomes. The framework further elucidates how market action becomes variably rational (Kalberg 1980; Weber (2017) [1920]) due to the impact of the justice macromotive, i.e. the general drive to uphold the commonly accepted norms of justice in marketing systems (Ferrell and Ferrell 2008; Lerner 2003). As marketing systems form and evolve, emerging institutional patterns influence marketing system participants (Layton 2015), variably structuring their market practices and shaping their views on the fairness of outcomes (Klein 2008; Laczniak and Murphy

\footnotetext{
'School of Marketing and International Business, Victoria University of Wellington, Wellington, New Zealand
}

\section{Corresponding Author:}

Djavlonbek Kadirov, School of Marketing and International Business, Victoria University of Wellington, Rutherford House, I109, 23 Lambton Quay, Pipitea Campus, Wellington, 6I40, New Zealand.

Email: djavlonbek.kadirov@vuw.ac.nz 
2008; Laczniak and Santos 2011). Hence, these actors initiate institutional change that legitimizes further action to reclaim a perceived loss of justice; yet, researchers do not understand the pattern of change, either for the market or for the participants. These shifts, which mostly require collective action, include the following: conceptualizing and developing common resource(s), shifting assets between public and private spheres, participating in marketing-system governance, and calibrating attenuative mechanisms.

This framework attempts to reconcile the rational, normative, and symbolic mechanisms of institutional change in marketing systems (Scott 2014), developing a holistic model to study adjustments and transformation in marketing systems. This research sets a theoretical foundation for better understanding how a marketing system can represent "common good" enterprises, in which a marketing-system may promote just market systems. In addition, this article extends Layton's (2015) MAS (Mechanism, Action, Structure) framework by proposing that marketing systems are structured as a "solution" which harbors unique (dis)benefits for its participants that are above and beyond of what products/services generated within these marketing systems could offer. This insight is important: it scrutinizes the assumption that societal well-being depends on the immediate output of markets (goods assortments, see Layton 2015), irrespective of how these marketing systems structure the meanings of value. This perspective can lead to misdirected market and policy decisions (Acemoglu and Robinson 2012; Laczniak and Murphy 2008; Sen 1999, 2005). Rather, our research implies that only when policy makers can see the demand for effective marketing systems as essential and citizens as the (macro) customers of marketing systems, will they likely be able to make decisions that really matter to citizens (Ferrell and Ferrell 2008).

The article is organized as follows: the key literature on marketing systems theory is briefly reviewed in the first section, in order to highlight the role of change in marketing systems. Next, the Marketing Systems-as-the-Public-Good framework is introduced and its main tenets are discussed, followed by a review of the justice macromotive, to highlight one of the potential sources of change in marketing systems. Finally, the case of the historical evolution of Uzbek Bozor Marketing System is presented to illustrate some of the key elements of the framework.

\section{Marketing Systems Theory and the Collective Drive for Change}

Marketing systems theory rests on the foundational idea that marketing represents a provisioning technology of society that can be reflexive as it can often bring change to society through its ability to influence dimensions of society, such as the economic, political, sociocultural, and technological dimensions of society (Fisk 1967, 1974; Fisk 1997; Kadirov and Varey 2011; Layton 2007, 2009, 2015; Mittelstaedt, Kilbourne, and Mittelstaedt 2006). Fisk understood marketing as a social process that must be seen (i.e. interpreted) from the perspective of stakeholders who experience spillover effects, in the form of both public "goods" and "bads." He further indicated that his reading of classic marketing thinkers (e.g. Alderson, Breyer, Cox) led him to believe that effective marketing systems meet human needs efficiently and flexibly while maximizing positive externalities. Although Fisk (1997) did not specifically discuss how marketing systems emerge and evolve, he emphasized the need of disenfranchised market actors-disenfranchised market actors influence technologies that ensure outcomes such as distributive justice, collective advance, improved quality of life, and long-run community flourishing. Since then, marketing systems theory has focused largely on the demand for goods/services assortments (Layton 2007) and questions regarding whether market actors "think" like macromarketers, and whether they comprehend systemic issues, whether they desire institutional change in society beyond markets.

Macromarketing research indicates that marketing systems arise as a solution to the problem of "demand heterogeneity" (Layton 2009; Mittelstaedt, Kilbourne, and Mittelstaedt 2006). Demand heterogeneity arises due to formal, informal, and philosophical antecedents (Mittelstaedt, Kilbourne, and Mittelstaedt 2006) as well as evolving market-mechanisms (Layton 2015). Somewhat counter to this, Fisk (1997) suggested that the demand at a micro-level was endogenously shaped and determined within marketing system structures. The current article puts these seemingly different logics together in an attempt to answer the following question: where does the drive for change, which goes beyond the immediate context of micro-level exchanges, fit in this framework? Recent evidence in macromarketing research attests to the desire for wellfunctioning, dignity-enhancing, just marketing systems, specifically among disenfranchised groups (Jagadale, Kadirov, and Chakraborty 2017; Laczniak and Santos 2011; Vulkan, Roth, and Neeman 2013). Collective "dissatisfaction" with marketing systems is rooted in systemic issues and reflected in "wicked" problems (Kennedy 2017). Market injustice, when it occurs, is clearly reflected in the experiences of marketing system participants (Klein 2008; Vulkan, Roth, and Neeman 2013). Consumers might accept solutions proffered by marketing system assortments that are offered at a micro level while they still seek desired macro-changes as observed in the example of American gun-violence-prevention groups (Huff et al. 2017). Continued attempts to "fix" problematic markets are undertaken when participants, despite transacting in these markets, end up feeling that the whole process was chaotic, inefficient and unfair (Roth 2008, 2013).

The drive for change becomes salient when actors' selfinterests align and intersect. The perspective of markets as the agora stresses this aspect of marketing systems that goes beyond exchange markets, which include political, sociocultural, technological, and institutional influences (Mittelstaedt, Kilbourne, and Mittelstaedt 2006). The agora perspective considers possibilities that some exchange practices of a group of market actors may impact the potential of demand satisfaction for other groups. Such impacts, generally understood as 


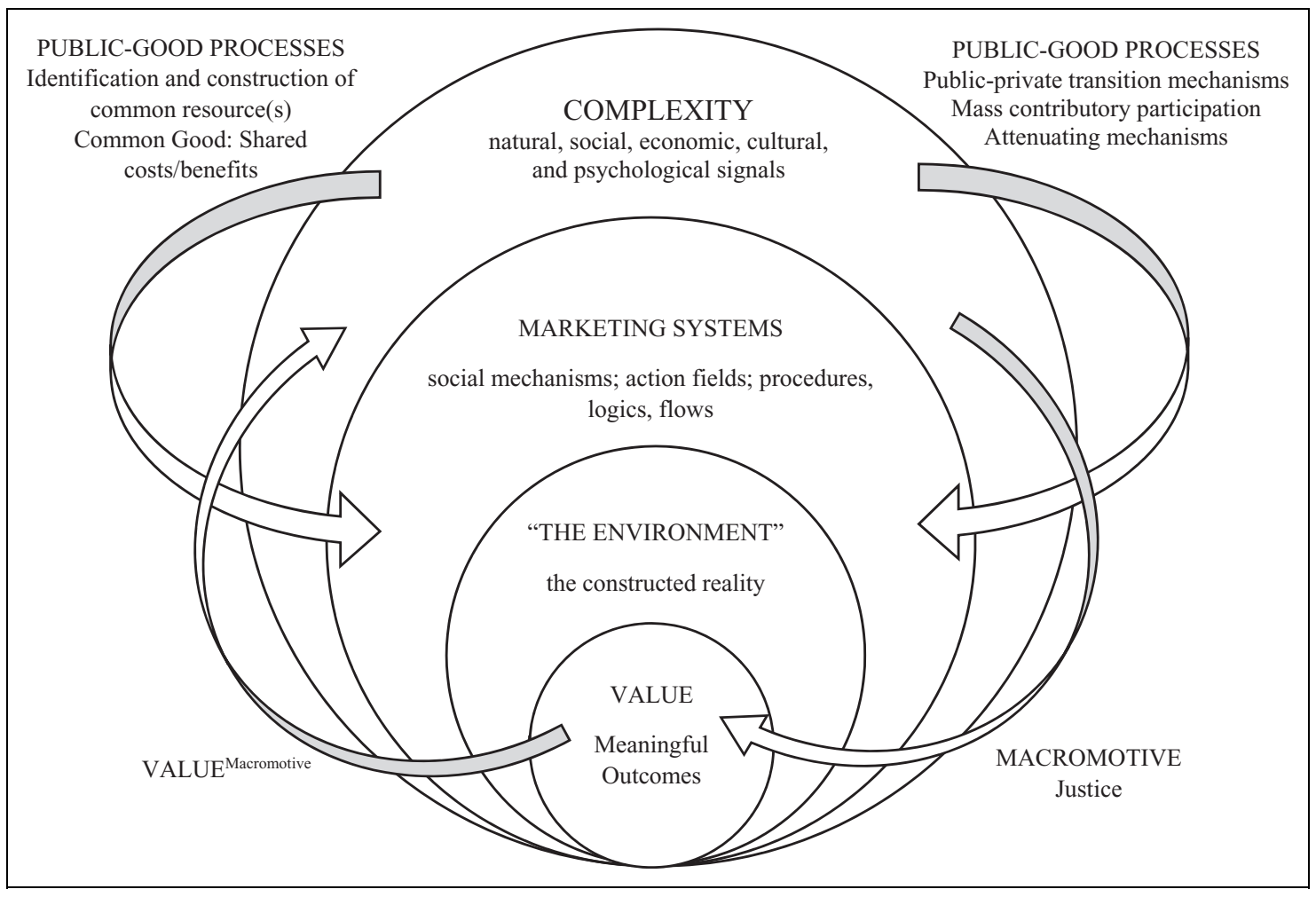

Figure I. The Marketing-Systems-as-the-Public-Good framework.

interdependence/interactivity, may not simply represent spillover effects; rather, these effects could well be at the heart of how marketing systems operate. The practices of a few market actors could introduce irreversible changes to the structure and processes of marketing systems, thus affecting the fortunes of masses. For example, the chrematistics-in-marketing systems approach offers a framework for studying influences of powerful market actors on the regulative mechanisms of marketing systems (Kadirov, Vary, and Wolfenden 2016).

Layton (2015) introduces the MAS framework to explain causal processes that influence how marketing systems emerge, grow and adapt. This framework comprises a number of marketing system elements (e.g. procedures, logics, roles, networks, governance) that arise under the impact of social mechanisms such as cooperation, specialization, and selforganization. Layton also discusses "action fields" that refer to a structured, organized environment in which marketing system participants interact while assuming specific roles. Layton notes that action fields are essentially existential (Layton 2015), that is, strategic actors attract others into the same sphere of action through promoting a sense of meaningfulness and moral legitimacy (Fligstein and McAdam 2012; Humphreys 2010; Scott 2014). However, internal meaningfulness may not be sufficient in itself; a systemic reform along an overarching value (e.g. justice) is required to uphold the system. For instance, Vikas, Varman, and Belk (2015) studied the caste-based Jajmani localized economic systems in India where willful coordination, cooperation and mutual solidarity between higher and lower castes was historically maintained through religious legitimation. However, market actors gradually came to realize the system's oppressive nature. The authors show that meaningfulness without justice gives rise to "symbolic violence:" social relations appear to be harmonious, while in fact they are based on ongoing moral humiliation of lower castes. Symbolic violence was reflected in practices whereby a member of a lower caste could access higher economic value while interacting with higher caste members, however, this relationship was structured in a way that it fundamentally humiliated the former, while reaffirming the superiority of the latter. The authors concluded that marketization trends disrupted what they call the "veil of enchanted relations" by raising the issue of fairness and the need for transformation, while at the same time creating a new form of symbolic violence between the newly rich and the poor.

Contributing to MAS theory, Haase, Becker, and Pick (2017) classify different outcomes of value creation processes: value for the individual (micro), social and ecological value for communities and groups (macro-1), and value for society or nature (macro-2). They argue that individuals are capable of assessing value at the micro and macro-1 levels, but may not be able to assess value at the macro-2 level. In contrast, the framework proposed in this article treats all types of value as anthropocentric constructions that attain meaningfulness and legitimacy within the structure (action fields) of relevant marketing systems. This framework offers an inverted picture of marketing systems where "value" and "the environment," as framed by the marketing system, are located within the system (Figure 1). Accordingly, the value that individuals derive from 
exchanges becomes "impregnated" (Selznick 2011) with what researchers call macromotive, or, the force that underscores the drive for change in marketing systems. Here, macromotive refers to the concern and preference for higher-order collective outcomes that links system-level structures to individual value creation (Blau 1964; Holmes 1981; Nielsen 2015). For instance, marketing system actors would not be content with the economic value that is not perceived to be fair (Lerner 1981). Such composite value allows market actors to interpret complexity in action, through their practices, giving rise to evolving dynamic changes in marketing systems.

\section{The "Marketing-Systems-as-a-Public-Good" Framework}

This section presents a conceptualization of marketing systems based on the notion of public good with a view to addressing the "correction" question from an alternative perspective. It thus tries to answer the following question implied in Layton (2017): what kind of correction or "evolutionary dynamic" should be introduced so that a marketing system follows a desirable path? Public good, in this context, refers to the characteristics of a marketing system where its (dis)benefits for actors evolve along the continua of excludability and subtractability - the degree one person's use of a resource diminishes others' use of it.

Figure 1 presents the broad view of the framework. This framework is based on the premise that a marketing system emerges as an interpretation (i.e. simplification, reduction) of complexity through collective action which involves: a) the identification, development and maintenance of key common resources; b) the interpretation, generation and modification of private-public good transitions; c) contributory participation of market actors in the development of private-public good mixes; and d) the construction of attenuating mechanisms that help calibrate the public good/badness of the system. Here, complexity refers to general indeterminacy caused by the complex confluence of natural, social, economic, cultural, and psychological signals.

The above framework is based on the insight that "the environment," as well as "value," or desirable outcomes, are endogenously determined within the system. This worldview is a core institutionalist premise for marketing system change (Scott 2014): actors' views of the surrounding world and what they consider to be valuable is dynamically shaped by institutional forces within action fields (Fligstein and McAdam 2012; Scott 2014). Action fields enable and constrain practices, engender macromotives, and generate meaningful agency within the system. Furthermore, desirable outcomes (i.e. value) take on different shades of meaning under the impact of macromotives. A specific macromotive (e.g. justice) is appended to a value as its qualitative dimension, which is indicated as $\left[\right.$ Value $\left.{ }^{\text {Macromotive }}\right]$. The macromotive can take one of its many possible specific forms, for instance: [Economic Value ${ }^{\text {Justice }}$ ]. Such composite value is dynamic. Its temporal dynamism is reflected in its different forms (e.g. economic, social, environmental, see Haase, Becker, and Pick 2017) and magnitude, while the "macromotive" superscript may also vary in its form (e.g. justice, survival, repugnance (Roth 2007)) and magnitude. Hence, these variations in value not only structure actors' interpretations, actions and practices but also inspire their collective action to activate system-level calibrations. It must also be noted that this framework does not affirm the moral superiority of one type of value over another. The elements of marketing system change framework will be further elucidated in the subsequent sections.

\section{Public Good Qualities of Marketing Systems Dynamic Reduction of Complexity}

Marketing systems emerge as a locus of human activity where the organized way of dealing with complexity enables various market solutions for different provisioning problems (Fisk 1967; Layton 2007). The view that the environment of a system is an inherent part of a system is not new (Layton 2007; Kadirov and Varey 2011). Layton (2007) highlighted this aspect of marketing systems indicating that a marketing system encompasses its own relevant environment, whereas Kadirov and Varey (2011) reviewed relevant research, summarizing the research as follows: a) the outer world is complex, and marketing systems emerge through a continuous effort to simplify this outer world; b) "the environment," the structured and meaningful view of the outer world, is replicated and created within marketing systems; and c) observed environmental changes can be differently interpreted depending on various circumstances of system actors. In addition, the process of complexity reduction is temporally dynamic, since complexity is in continuous flux. The market design studies conducted by Alvin Roth (2008) and his colleagues (refer to Vulkan, Roth, and Neeman 2013) indicate such dynamism: efficient markets are those that can continually deal with congestion (i.e. the complex entanglement of actors, interests, and practices) and offer simple ways of transacting safely. From this perspective, markets are formed when a sufficient proportion of actors are attracted to the simplified environment of the market (e.g., "thickness").

Complexity reduction is a macro rationalization process that constructs systemic structures that imbue action with meaning (Weber (2017) [1920]). "Rational" action is the product of historical development. It transforms and evolves, and it has a multiplicity of forms (Kalberg 1980; Weber (2017) [1920]). In the proposed framework, the assumption is that market actors continually attempt to rationalize their actions by collectively constructing and reconstructing marketing systems which render desired "value" meaningful. It is in contrast to the assumption that actors directly pursue an exogenous, taken for granted value, while systems structures emerge as a byproduct of these activities (Layton 2015). 


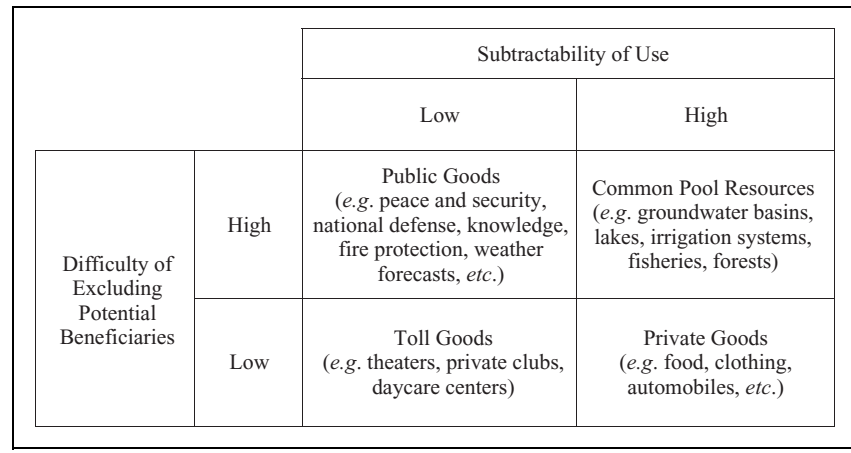

Figure 2. The output of marketing systems: The goods typology (adapted from Ostrom 2005).

\section{Marketing Systems' Output: Creation of Common Resource(s)}

Marketing systems offer assortments that combine the characteristics of the following types of goods: private goods, club/toll goods, public goods, and common-pool resources. Originally, Samuelson (1954) made a distinction between private and public goods based on two properties: a) "rivalry," i.e. the extent to which one's use of a good reduces this good's availability to others; and b) "excludability," i.e. the extent to which one can be excluded from its use. Samuelson argued that private goods are rivalrous and excludable, whereas public goods are non-rivalrous and non-excludable. He defined public goods as those "which all enjoy in common in the sense that each individual's consumption of such a good leads to no subtractions from any other individual's consumption of that good" (p. 387).

Prior to Samuelson's distinction, the indivisibility of use for some market assortments has been recognized by Mazzola ((1958) [1890]), Wicksell ((1958) [1896]), Sax ((1958) [1924]), Viti de Marco (1936), and Bergson (1938). As the theory of public goods did not fit well in neoclassical thinking, microeconomics dealt with the issue in two ways: a) public goods were conceptualized as a specific type of externality (Cornes and Sandler 1996; Mas-Colell, Whinston, and Green 1995); and b) public goods were considered outside of competitive markets, the domain that economists called public services (Ostrom and Ostrom 1977). To improve the theoretical groundwork, Ostrom and Ostrom (1977) redefined "rivalry" as "subtractability," in the sense that one's use of a good might, to a certain degree, subtract the usefulness of this good for others. In other words, they argued that most goods fall between being perfectly subtractable goods (e.g. a loaf of bread), which have the capacity to serve only a single market actor or a group, and perfectly non-subtractable goods (e.g. public defense) which serve everyone at the same time. From this perspective, the spillover effect of quid pro quo exchanges becomes the rule rather than the exception, while the severity of would depend on the extent of the good's availability, subtractability, and excludability. Figure 2 depicts the four types of marketing system output.
The subtractability and exclusiveness characteristics are not to be taken as a binary; rather they vary in degree (Ostrom and Ostrom 1977; Ostrom 2005). Although the typology given in Figure 2 depicts common cases only, goods/choices are actually made available within marketing systems in a highly heterogeneous and multilayered fashion. The options generated fall anywhere between the extreme points, and therefore, most goods can be considered as impure public goods (Cornes and Sandler 1996; Kotchen 2005). To note, the broader view of marketing systems which is proposed in this article is not confined within the boundaries of competitive markets only (i.e. private goods), as competitive markets cannot exist without foundational infrastructure enabled by public goods such as peace, education, health, knowledge, technology, transportation, and the Internet, as well as specific public goods closely related to the functioning of specific marketing systems. From this perspective, "private" represents a solution (i.e. a marketbased interpretation) that creatively combines common resources made available through societal commitment to public good provisioning.

The notion of an impure/mixed public good recognizes the complex nature of market offerings, whereby a good is assumed to contain both private and public benefits, as in the case of green products (Kotchen 2005). Even a highly private good such as a meal can have public benefits if it is a healthy meal (Kaul, Grunberg, and Stern 1999). Foldvary (1994) provides an excellent review of relevant literature and a number of case studies that show that most public goods are spatially bound, and hence, they can be seen as "territorial." To clarify, the existence of a public good enhances the livelihood quality of the territorial area that is reflected in rent paid to landowners. Foldvary argues that the desirability of moving to the area and migration patterns would indicate the extent to which public goods enhance the value of a certain area. Following the same reasoning, I note that the creation of relevant public goods, i.e. the identification, development and cultivation of common resources, serve as the bedrock of marketing system growth. Common resources do not only revitalize and intensify a marketing system, but also generate dynamic impacts within the structure, functions, and action fields of the marketing system.

\section{Common Good: Shared Costs and Benefits}

The view of marketing systems representing a public good draws from institutional economics theory, specifically the social costs perspective (Kapp 1970, 1978), valuation systems theory (Gilles and Diamantaras 2005), and the inclusive/extractive institutions framework (Acemoglu and Robinson 2012). Analyzing the politico-economic dimension of systems encompassing market activities and their complex, unmeasurable non-market impacts in the form of social costs, Kapp (1978) suggested that an economic analysis of business activities should take into account complex social costs/benefits imposed on third parties or society at large. Kapp insisted that such systems, when constructed effectively to ensure the stable generation of social benefits rather than costs, should be 
recognized as public goods due to their non-rivalness and non-excludability. Kapp (1970) maintained that the market/ economic system at large represented an out-of-market phenomenon, and therefore could not be adequately assessed using the market logic that is based on endogenously defined specific economic measures such as profit or wealth. In fact, he believed that decisions (about social minima) must be politically debated and imposed, as no cost-benefit analysis would be able to assess the importance and impact of this public good.

In contrast, valuation systems theory presupposes that the price system (the vector of all prices in exchanges) in society inherently reflects a specific configuration of a market system, while different potential market configurations would entail different regimes of utility gains and losses for market actors (Gilles and Diamantaras 2005). In view of this dynamic, Gilles and Diamantaras (2005) posit that "a market system could explicitly be recognized as a multi-faceted collective good ... chosen collectively in view of its benefits and costs to the society as a whole" (p. 51). The authors argue that the establishment of a marketing system as an overarching structure occurs as society decides what parties should receive subsidies, and which parties should be taxed to cover the cost of these subsidies. These implicitly agreedon institutions thus take the form of a valuation system, or an interpretive frame, which arises as a specific collective arrangement.

Analyzing market systems from the viewpoint of the desirability of economic growth (i.e. value), Acemoglu and Robinson (2012) highlight the historical role of complexity-reducing valuation systems in the development path of many nations. These systems are shown to comprise both economic institutions (e.g. property rights, ownership, innovation, incentives, metrics) and supporting political institutions (e.g. government, laws, rules and regulation, power distribution). The authors attribute global inequality in wealth to varying degrees of inclusiveness, which is seen as the extent of participation that population has in making significant decisions concerning major societal and economic issues. They see economic inclusiveness as the direct result of political inclusiveness whereby people increasingly participate in the governance of marketing systems. The authors show how supposedly marginal steps toward greater inclusiveness, taken in early phases, could lead to significant outcomes, thus highlighting the importance of the public-goodness characteristic of marketing systems. They argue that market systems attain desirable growth through gradually developing greater inclusiveness, while also continually investing in unsubtractable services such as peace, national defense, knowledge and know-how, financial systems, education, healthcare, road networks, and other infrastructure. In contrast, "extractive systems," defined as institutions designed to extract wealth from the majority for the benefit of the selected elite (perhaps representing "public badness"), are driven by the motive of perpetuating "status quo" rather than "growth" as a guiding value.

\section{Public-Private Transition Mechanisms}

Markets comprise complex fields of action in which transformations from one type of good to another are in a state of constant flux. Depending on what property rights, rules, regulations, and mechanisms are in action, private markets tend to arise as an emergent outcome of interactions among many stakeholders. The Institutional Analysis and Development framework advocated by Ostrom $(2005,2010)$ allows for the view of marketing systems as polycentric governance domains in which private exchanges are but a miniscule part of complex human interactions. The purpose of the framework, as seen by many researchers-including its advocates -is to investigate complex human systems governing common-pool resources. Ostrom's framework can also be used as a general method for analyzing how private exchange markets and their boundaries are established through public-private good transformations. Analyzing how micro-action fields (e.g. private exchange) emerge within broader economic systems, Ostrom (2005) recognizes a number of mechanisms at work such as property rights bundles (e.g. access rights, withdrawal rights, alienation rights), rules-in-use (resource use rules, payoff rules, boundary rules), and system-design principles (e.g. user/resource boundaries, user/resource monitoring, appropriation and provision). Moreover, Ostrom highlights the importance of cooperation, preferences regarding others, and community sanctioning as fundamental conditions for the emergence of well-functioning systems.

A shift from a public to private good at the output level can parallel a simultaneous shift from non-inclusiveness toward inclusiveness. Echoing Acemoglu and Robinson's (2012) analysis of a shift from extractive to inclusive systems, Layton (2015) observes the emergence of the Hubei Longlake Freshwater Fish Marketing System where rights bundles, rules-inuse, and design principles have evolved to a significant extent as the Chinese authorities initiated the "Household Responsibility" program. As Layton observes, under the state-owned Longlake Fishing Farm arrangement, the output was essentially treated as a public good: i.e. something that must "belong" to the whole nation. However, in practice the output was only available to designated groups, and distributed through specific collectives and state-owned channels. The old arrangement was extractive in the sense that the state was an exclusive authority governing rights, rules, and design principles. Since the Communist party elites guided decision making, such a system, taken on a macro-scale, paradoxically became akin to a provisioning technology featuring the characteristics of a toll/private good. As the system evolved and the government relaxed its hold on the market, the system has become more inclusive, involving an increasing number of participants who now were able to contribute to the construction of complex action fields, social mechanisms, rights, rules, and design features (Layton 2015). The provisioning system has thus gradually shifted in the opposite direction, assuming the features of a public good. 
Inclusive marketing systems ensure a healthy balance of private and public goods at the output level. The two domains co-evolve and differing degrees of subtractability and exclusion are shaped through a diversity of transition mechanisms (Ostrom 2005; Layton 2015). There are two distinct milieus in which public-private good transitions occur: the same good and complementary goods. In the same good context, the status of the same resource can go through various transformations. For instance, Ostrom (2010) describes an array of specific rules of transformation used in different settings. Ostram considers the specification of conditions, timing, amounts, and agents for withdrawing from the pool of common resources. Similarly, Layton (2015) documents how the same resource (i.e. fish stocks in Hubei Longlake) is treated differently depending on the evolution of the marketing system. In contrast, in the complementary goods context the success of a private good is dependent on a related array of public goods. Galbraith (1958) emphasized an organic evolution of public and private goods, giving an example of how a filthy public park or a camping ground (i.e. the natural environment) inhibits the enjoyment of high-quality camping equipment and related assortments. He argued that both types were needed for the advancement of societal well-being. Their co-evolution is required: a well-functioning marketing system should ensure that citizen experiences are complete. Similarly, Kadirov (2011) shows the private-market output cannot replace the unique impact of the natural environment on societal welfare. Hence, both domains must co-evolve. The examples of such co-evolution are abundant. Modern cars need good roads, while electronic products depend on access to the Internet and national power grids. The recent financial crisis in the United States made it clear that the financial system at large represents a public good (Redmond 2013). What should be emphasized is that marketing systems comprise simultaneous, parallel action situations in which the same good could be treated as a private good for some, while to others it is treated as a public good. Such differences are underscored by the degrees of subtractability and exclusion activated within these action situations. It should also be noted that real improvements are attained when rule-making and design decisions are inclusive.

\section{Mass Contributory Participation}

A marketing system in the form of a public good arises when individual agents participate in shaping rules and norms governing the generation of different assortments of private/public goods. From the new classical economics perspective, market actors are viewed as consumer-producers (Yang 2003; Gilles and Diamantaras 2005). The main assumption within this framework is that individuals maximize utility by selecting an optimal mix of market engagement, while specific roles (e.g. consumer, producer) are assigned ex-post. It is assumed that technology is publicly available gratis which has been previously created. Hence, the total input/output is not only a private good, but also a public good based on "free gifting" (Varey, Sörhammar, and Kadirov 2015).
Market design studies (Roth 2008; Vulkan, Roth, and Neeman 2013) highlight the importance of market actors' collective action during direct regulative market intrusions by those in authority. Based on the evidence from several markets subjected to regulative change (e.g. job markets, transplant organs exchange, public school enrolment, energy markets), researchers suggest that participation not only provides market "thickness", but also continually transforms the markets, which would require additional cycles of regulation (Roth 2013).

Extending the service-dominant logic, service research scholars adopted an alternative terminology to explain the dynamic, symbolic, and participatory nature of marketing systems (Vargo and Akaka 2012; Vargo et al. 2017; Vargo and Lusch 2016). Concomitant to Layton's (2015) concepts of marketing systems, Vargo and Akaka (2012), Vargo et al. (2017), and Vargo and Lusch (2016) defined "service ecosystems" in an analogous fashion, suggesting that service ecosystems are the collection of resource-integrating market actors linked by common institutions (Vargo et al. 2017; Vargo and Akaka 2012). They suggested that there are no consumers or producers, per se, in service ecosystems. Rather, all actors are resource integrators. These actors are engaged in co-creative practices aimed at attaining desired outcomes such as collectively created value. Vargo and Akaka (2012) argue that these actors simultaneously construct, perpetuate, and develop the very service ecosystems in which they operate. These actors benefit from these systems in the sense that they are able to continually pursue their marketing/consumption ends within the normative and symbolic boundaries of these systems. Hence, the authors believe that service provisioning necessitates parallel contributory participation in the design of service ecosystems.

In the same vein, consumer research shows that people seek greater participation in processes governing private-public good transformations. For example, consumers tend to challenge established market structures, and seek profound changes in marketing practices when they are not satisfied with either benefits or costs flowing from these market structures (Giesler 2008; Kozinets and Handelman 2004; Scaraboto and Fischer 2013). Analyzing marginalized consumers seeking greater inclusion in a market, Scaraboto and Fischer (2013) describe different tools and strategies available to consumers. The authors' qualitative inquiry shows that "frustrated fatshionistas"-plus-sized consumers - used various legitimization strategies such as introducing the institutional logics of the Fat Acceptance Movement into the mainstream market. As a consequence, the fashion market has become more inclusive and the variety of assortments has increased. This case illustrates the importance of establishing flexible sociocultural mechanisms through which markets can be expanded to include various idiosyncratic demands, which may not always be possible in different contexts.

Theories of market shaping highlight broad sociocultural participation as the foundation of the "market" phenomenon. From this perspective, markets represent practical outcomes of different actors' ongoing efforts (Araujo 2007; Kjellberg and Helgesson 2007; Nenonen et al. 2014). Market shaping occurs 
through participation of various stakeholders (e.g. businesses, consumers, governments, academics, communities) in creating a dynamic consensus of what markets are and how markets (should) work. Kjellberg and Helgesson (2007) argue that markets consist of not only exchange practices, but also normalizing (i.e. creation of rules and norms) and representational practices (creation of mental models of how markets work). Through engaging in these practices, market actors are said to perform the market (Araujo 2007). Nenonen et al. (2014, p. 271) define markets as "ongoing socio-material enactments that organize economized exchanges." They argue that markets are distinguished by their plasticity, by the ability to take and retain form. Accordingly, resultant market structures tend to be highly contingent on market actors' situated choices, relationships within networks, power relations, and opportunistic acts.

\section{Attenuating Mechanisms}

In line with the notion of dissipative structures, Kapp (1978) explicated the principle of "cumulative causation," according to which economic systems constantly move away from an equilibrium point under the impact of both economic and noneconomic influences. As a result, a small change could cumulatively force global changes in the system; or, progress in a risk-laden direction may not be easily stoppable, especially when there are no countervailing forces in action. Bateson (1991) discusses schismogenetic processes in complex systems, and argues that a complex system can be characterized by regenerative causal circuits. A cumulative effect within these causal circuits may increase in intensity to the extent that the general health of the system may become jeopardized. Acemoglu and Robinson (2012) provide many examples of such cumulative effects in the context of economic development challenges in many countries. A recent example is the crisis in the U.S. financial system whereby questionable practices spiraled out of control shortly after involved parties successfully dismantled the safeguarding systems of regulation and controls (Redmond 2013). Arguably, the existence of opportunism necessitates the introduction of appropriate mechanisms that counteract and neutralize harmful tendencies characterized by cunning self-interest (Williamson 1985).

From the logic of marketing-systems-as-a-public-good, complex human systems tend to include attenuating mechanisms that discourage cumulative processes if such processes exceed communally agreed limits of justice (Kapp 1978). Attenuating mechanisms are societal arrangements that are designed to thwart, counter-react to, and reverse potentially harmful tendencies. Such institutions may include government laws and regulations (e.g. anti-trust regulation), industrial selfregulation, social norms and expectations, implicit social contract, societal movements, moral codes, whistleblowing, and marketing system actors with specific regulative functions. For example, the role of credit rating agencies in the U.S. housing market crisis should be re-evaluated from this perspective, as these agencies were expected to play a crucial role in discouraging toxic security trade through realistic (re)assessment of mortgage-based securities (Redmond 2013).

Drawing on the insights from a number of empirical studies, Stiglitz (2014) introduces the notion of excessively active markets and argues that such markets have adverse effects on both broader economic systems and society at large. He shows that some markets (e.g. innovative products, derivatives, crossborder capital markets) might become excessively active, and thereby inefficient. This is based on the general result that unfettered markets with information asymmetries and underdeveloped risk control are inefficient, while the introduction of a relevant regulation has a potential to improve the state of the system. Stiglitz (2014) notes that "while there are no easy answers, a plausible case can be made for tapping the brakes: Less active markets can not only be safer markets, they can better serve the societal functions that they are intended to serve" (2014, p. 14).

\section{Macromotive Theory}

\section{The Value of Value Creation}

The Marketing-Systems-as-a-Public-Good framework is built on the premise that a marketing system evolves in reaction/ anticipation to desired value changes, while at the same time serving as an institutional foundation for the meaningfulness of value creation (Scott 2014). This happens via a macromotive which links individual value perceptions to higher-level system structures. The concept of macromotive refers to the drivers of individual behavior that reflect concern and preference for higher-order collective outcomes, rather than merely individual benefits (Blau 1964; Holmes 1981; Nielsen 2015). Attempting to bridge the micro-macro divide, social exchange theorists argue that social exchange, in contrast to commercial exchange, is characterized by a macromotive: individuals rationally expect that societal/reciprocal obligations will be duly discharged by others (Homans 1961; Blau 1964; Nielsen 2015). Although social exchange theory is a utilitarian framework, its key assumption is that positive higher-order patterns reinforce micro-level behavior (Homans 1961). On a smaller scale, Holmes (1981) analyzed macromotives in close relationships: they were shown to be driven by higher-order consequences such as love, commitment, and trust.

This article proposes that marketing system actors relate to society's aggregate marketing systems beyond what the neoclassic view prescribes: the rational pursuit of individual value (in its many different forms). It is expected that citizens would harbor a macromotive of belonging to and operating in meaningful marketing systems, while their phenomenological experiences of what "value" is might depend on a variety of geopolitical, sociohistorical, and cultural factors. Although it is not possible for individuals to grasp the totality of marketing systems in their personal life-worlds, they would still be capable to make higher-order judgements based on "thinslice" evidence. 
In general, the macromotive perspective reverses the dominant micro-macro logic, which is conventionally based on an assumption that micromotives, i.e. rational individual decisions, cause (un)desirable macro consequences (Hardin 1968; Crozet and Lopez-Ruiz 2013; Shultz and Holbrook 1999). In contrast, a macromotive is seen as a tendency to stray from a predicted path of self-serving interest and to act as though a common interest is paramount; some researchers tend to explain this elusive phenomenon as an aberration or a byproduct of social processes (Lerner 1977, 2003). Macromotives are observed in different contexts. For example, the commercialization of national wealth, considered invaluable (e.g. water, indigenous land), tends to create deep societal discontent despite offering practical solutions for complex provisioning problems (Patsiaouras, Saren, and Fitchett 2015). Moneybased markets designed for kidney exchange may solve many problems, however, the repugnance of selling/buying transplant organs constrains the potential of such markets (Roth 2007). Similarly, despite the sufficiently high quality of life in affluent societies, an increasing number of people find themselves in dismay over unsustainable market systems and growth-driven trends (Varey 2013; Haase, Becker, and Pick 2017).

\section{The Justice Macromotive}

One of the specific macromotives that links structural change to individual action in marketing systems is the justice motive. The justice motive refers to the concern about societal justice, specifically, the belief that people (should) get what they deserve (Lerner 1977, 1981, 2003; Lerner and Lerner 1981; Montada 2002). The feelings related to whether people deserve their fates (e.g. social outcomes) are continual and immediately compelling (Lerner 1981). The sense of justice develops early in the child's development process, which arises as a corrective mechanism to direct self-interest maximizing motivations (Lerner 1977, 1981). As the child grows up, he/she realizes that the immediate gratification of desires is not always possible and that the investment of suitable resources (e.g. time, effort) will bring about appropriate (i.e. fair) outcomes. Such personal thin-slice experiences will eventually add up to the construction of the belief in the "just world" which is underscored by a conviction that people deserve their fate (Furnham 2003; Lerner and Miller 1978).

The justice motive theory is closely related to marketing systems theory, because it is inherently concerned about how people understand the rules/norms of resource acquisition and allocation (Ferrell and Ferrell 2008; Lerner 1981). Most people engage in self-maximizing behavior only if they deem it justified or fair (Lerner 2003). Rawlsian analysis indicates that just social systems could emerge as a result of rational behavior (Laczniak and Murphy 2008). Value creation presupposes justice; it is evident in situations when no amount of increased provisioning would appease a person if he/she sees it unjustified, and similarly, no amount of increased scarcity would dishearten a person if it is seen to be fair (Lerner 1981).

Justice is at the heart of value creation, yet its specific meaning could only arise within the constraints of a marketing system. People might harbor a general drive for justice, however, it remains an empty "container" unless it is infused with institutional meaning. For instance, there are many forms of institutional justice which can structure corporate action at a macro-level (Ferrell and Ferrell 2008; Klein 2008). Selznick (1969) studied how industrial relations and a degree of organizational bureaucratization affected contrasting employee perceptions of fairness. He argues that "industrial justice" emerges when managers infuse their goals and behavior with generally accepted expectations of fairness. McAdam (1996) discussed meaning creation (framing) tactics in civil rights movements and concluded that the illumination of context-specific injustice tends to align individual interests, and thus, motivate collective action.

The drive for collective action emerges when people see value outcomes in the background of marketing systems - who is entitled to what is judged, formally and informally, according to the established cultural standards of justice (Lerner 1981). In addition to reinforcing the predominant patterns of resource provisioning and allocation through market institutions, the justice macromotive also structurally mediates the definition of what the desired "resource" is. As it is often the case, societies determine, through collective/political contestation, how much of a resource is to be made available, while at the same determining who shall have access to how much of that resource (Calabresi and Bobbitt 1978; Vann and Kumcu 1995). A case in point is the Patient Protection and Affordable Care Act (Obamacare) that establishes health insurance in the USA as an invaluable resource that is a) a universal human right; b) too important to be left to the dehumanizing mechanisms of free market allocation; and c) to be fairly distributed across various groups in society. At the same time, the act's opponents also cite justice based arguments: healthy people should not bear the costly burden of the sick, or, people should not become fully dependent on the government. Thus, the justice macromotive links a person to the structure and governance of marketing systems via the judgments based on one's ability to access market assortments that one deserves as well as on whether any other citizen would be able to claim his/her fair share. The justice motive is the force of both change and stability. If injustice fuels action for change, perceived justice inspires the opposite (Furnham 2003). In most circumstances, people would be willing to sacrifice personal interests, or even their lives, for the protection of justice (Lerner 1981, 2003).

Table 1 summarizes the main axioms of the framework and the related theoretical propositions. Subsequently, a historical account of Uzbekistan's Bozor Marketing System is presented to illustrate the key axioms of the Marketing Systems-as-theMacro-Good framework.

\section{Illustrative Case: Uzbekistan's Bozor Marketing System}

\section{Research Method}

This illustrative case is based on my life-long ethnographic focus on localized market phenomena in Central Asia. Having 
Table I. Key Axioms and Theoretical Propositions.

\begin{tabular}{|c|c|c|c|}
\hline Elements & Orthodox view & $\begin{array}{l}\text { Marketing-Systems-as-the-Public-Good } \\
\text { framework }\end{array}$ & Theoretical propositions \\
\hline System & $\begin{array}{l}\text { A marketing system } \\
\text { emerges as the result of } \\
\text { micro-individual action. }\end{array}$ & $\begin{array}{l}\text { A marketing system is built as an overarching } \\
\text { institutional framework within which } \\
\text { individual action and desired outcomes are } \\
\text { enabled. }\end{array}$ & $\begin{array}{l}\text { A multiplicity of marketing-system designs are } \\
\text { possible. Notwithstanding peculiar design, } \\
\text { action within the system will seem rational } \\
\text { (justified) from the actor's perspective. }\end{array}$ \\
\hline Resources & $\begin{array}{l}\text { Key resources are } \\
\text { exogenous and part of } \\
\text { the environment. }\end{array}$ & $\begin{array}{l}\text { Key resources are conceptualized and } \\
\text { constructed within marketing systems. }\end{array}$ & $\begin{array}{l}\text { Creativity in identifying and building key resources } \\
\text { will fuel the marketing system. }\end{array}$ \\
\hline $\begin{array}{l}\text { Common } \\
\text { Good }\end{array}$ & $\begin{array}{l}\text { Marketing system actors } \\
\text { (co)create variable } \\
\text { outcomes for(with) each } \\
\text { other. }\end{array}$ & $\begin{array}{l}\text { In addition to micro outcomes, a marketing } \\
\text { system harbours non-excludable and non- } \\
\text { subtractable (dis)benefits for actors. }\end{array}$ & $\begin{array}{l}\text { Actors will collectively aspire to maximize the } \\
\text { non-excludable and non-subtractable benefit(s) } \\
\text { of marketing systems. }\end{array}$ \\
\hline Motives & $\begin{array}{l}\text { Market action is driven by } \\
\text { the self-interest motive. }\end{array}$ & $\begin{array}{l}\text { Macromotives structure micro-motives (e.g. self- } \\
\text { interest). }\end{array}$ & $\begin{array}{l}\text { Actors will interpret their action in the light of a } \\
\text { specific macromotive (e.g. the justice motive) } \\
\text { and calibrate collective action accordingly. }\end{array}$ \\
\hline
\end{tabular}

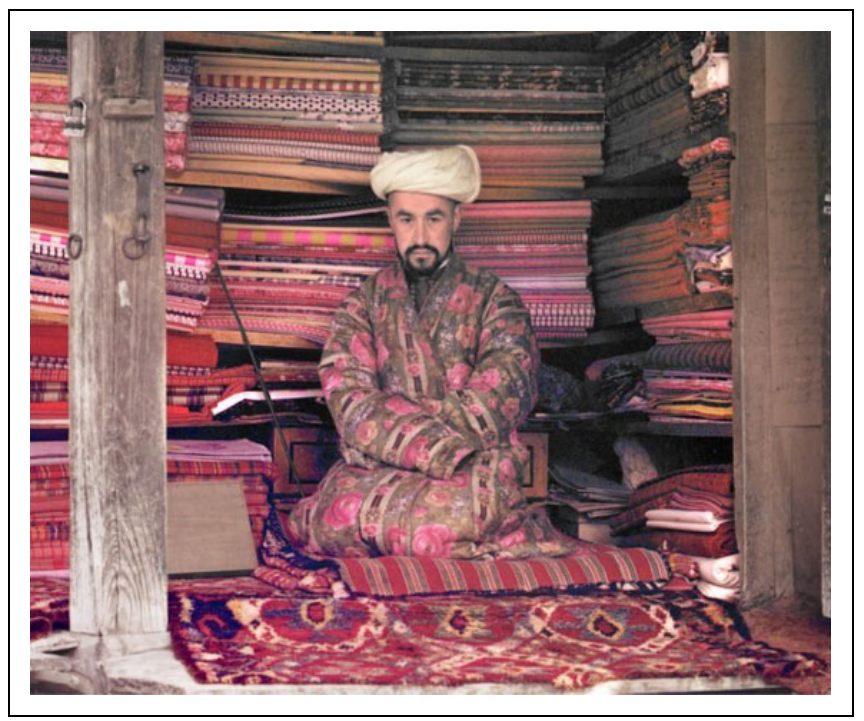

Figure 3. A fabric merchant in Samarkand circa 1900s (Source: Library of Congress, the Prokudin-Gorskii collection).

lived for more than three decades in Uzbekistan, I experienced the resurgence and evolution of bozor first-hand in both the Soviet and post-Soviet periods. My competence in Uzbek culture, history, literature, economy and politics, as well as locally used dialects, vernacular, and idioms of Uzbek, Russian, and Tadjik helped me develop a close understanding of the context and relevant processes. Although the preliminary collection of data (personal observation, ethnographic interviews, unstructured conversations, historical accounts, audio-visual material and artefacts) commenced in 1999, the systematic collection of further focused information started in 2015. The case presented in this article draws on a fraction of this immense volume of rich material to illustrate the core aspects of the proposed framework. To analyze this material, I followed the symbolism-based interpretive methodology developed by Kadirov and Varey (2011).

\section{Why is Uzbek Bozor a Marketing System?}

In modern-day Central Asia, bozor (i.e. market, bazaar) refers to a spatially bound, culturally mediated, communally constructed, complex, and at the same time, ordered system of life provisioning (Spector 2017). It represents a spatially coherent "action field" (Scott 2014), a diffuse network of nearly identical local markets underscored by evolving regulative, normative, and cultural-cognitive institutional elements. In this locus, the regulative fervor of those in authority (e.g. khans, clergy, the Soviet government, and the current state authorities) clash with, but also at times enmesh with the normative and cultural/ symbolic practices of its participants. In addition to its major function of exchange facilitation, bozor in Uzbek society serves as the spatiotemporal locus of political and religious activism, power struggle, labor relations, communication, information exchange, business deals, credit and finance arrangements, law enforcement as well as criminal activity, entertainment, social security and reciprocity provisions, community services, charitable action, and cultural traditions. Bozor is a provisioning technology (Fisk 1967); Uzbeks say "otang-bozor, onang-bozor" the literal translation of which is, "bozor is one's both father and mother," meaning that one's life can be wholly sustained through the bozor system. It, in its multiplicity and variation, represents a microcosm of Uzbek life (Zanca 2010).

At the current count, Uzbekistan, a home for 30.7 million people, has 595 bozors out of which 59 are one-day temporal markets (Uzbekistan National News Agency 2017). While most bozors function in similar ways and offer comparable 


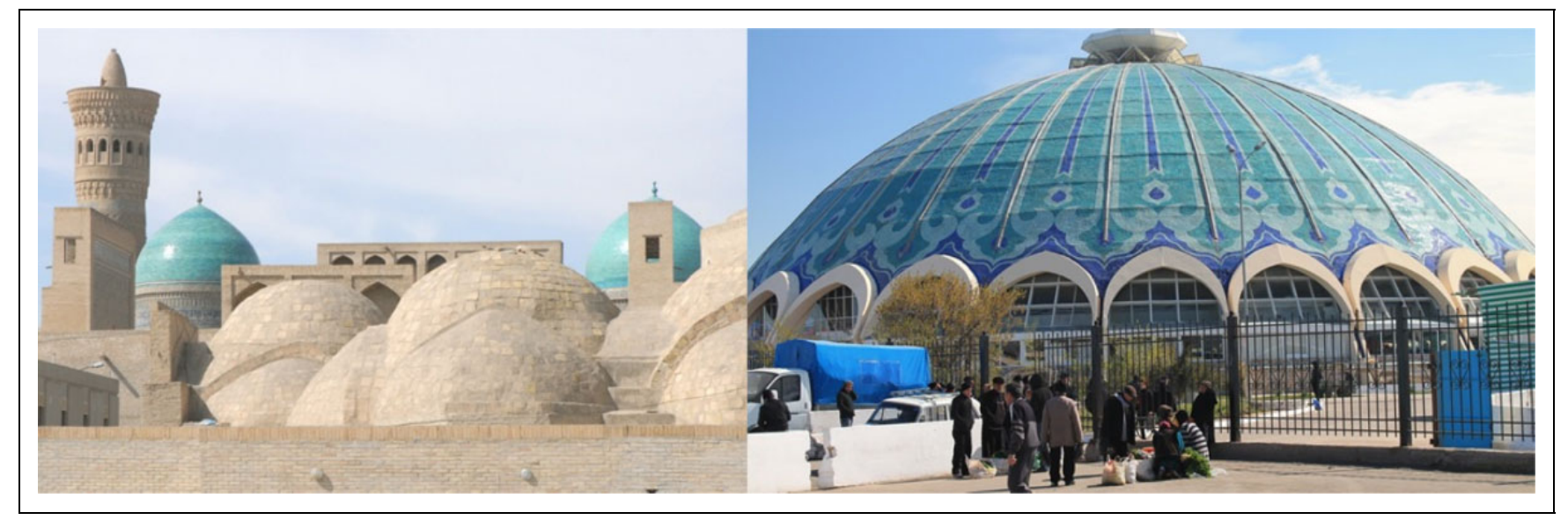

Figure 4. Guardianship over bozors was expressed in massive domes built over them: a tim (a trade complex) from the Great Silk Road Era in Bukhara (left) and the dome of Chorsu Bozor in Tashkent from the Soviet period (Sources: Wikimedia Commons; accessed at https://commons. wikimedia.org and Creative Commons; accessed at https://www.flickr.com/photos).

services, they are characterized by a unique concentration of specialized traders. My numerous interactions with the informants indicated that, for Uzbeks, bozor is not simply a locus of exchange; rather it is abstracted to connote a way of life as well as a unique prism of sense-making. Traditionally, people believe that one must visit a bozor at least once a day, specifically in early mornings, where one can source non-qaymoq (freshly baked bread and locally-made cream), while meeting friends, relatives, business partners or other contacts to sort out daily business. Acculturation to bozor happens from young age: an informant recalled the most vivid experience from his childhood (the Soviet period) that was to wake up before the sunrise to go to a bozor to purchase milk, cream, and bread, while he would often find a crowd of people selling and buying from very early in the morning.

\section{The Great Silk Road Period}

From ancient times, Central Asians capitalized on provisioning opportunities arising from the geopolitical location of major trade routes, one of them being the Great Silk Road (Beckwith 2009; Haksöz, Seshadri, and Iyer 2011; Kuzmina 2008). Metaphorically, trade routes represented "fertile rivers" of commercial opportunity remotely resembling natural common-pool resources (Duffy, Layton, and Dwyer 2017), the difference being that the former were man-made. Central Asians not only recognized this "resource," but also nurtured, developed and protected it, while integrating it with local commercial systems (Beckwith 2009; Haksöz, Seshadri, and Iyer 2011). This not only allowed the development of the bozor as a trade institution, but also the internationalization of local offerings (Duan et al. 2017; Haksöz, Seshadri, and Iyer 2011). Both public and private resources were devoted to the creation and maintenance of a vast network of caravanserais/rabats to facilitate the movement of goods through the harsh climate and terrain (Kuzmina 2008). The universal hospitality rule, which still survives, required free stay, food, and care for the travelers for at least three days (Haksöz, Seshadri, and Iyer 2011). The management of caravan flow was a key factor in the pre-industrial design of major trading cities where major arterial routes through city gates led straight to agora-like complexes composed of trade centers (tim), domed markets (taq), craft shops, money exchange centers, caravanserais, court rooms, public baths (hammom), charity houses (honaqoh), educational centers (madrasas) and mosques.

The macro-good processes were reflected in religious legitimation of shifting wealth from the private sphere to the public one (e.g. voluntary charity), which was closely associated with the maintenance and construction of rabats, bridges, and covered water reservoirs along trade routes (Khvandmir (1979) [1558]). During this period, several institutions acted as attenuating mechanisms. Commercial contracts were governed by the principles set in the Hanafi School of the Islamic Sacred Law which emphasized mutual agreement, dispute avoidance, harm minimization for both parties, and the importance of local traditions in resolving disputes. Another formalized institution was the office of muhtasib (i.e. the inspector of general weights and standards) that had extensive jurisdiction over marketplace issues (e.g. fair prices, correct weights, fair trade and legal contracts), public health and sanitation, food safety, and public misconduct (Mottahedeh and Stilt 2003). Moreover, most artisan groups were closely linked to various Sufi orders that emphasized virtues such as generosity, greed aversion, and the undesirability of excessive wealth accumulation. These institutions were not always perfectly effective, especially when powerful groups (e.g. rulers, khans, judges) abused their sweeping powers, but these mechanisms at least guaranteed that the bozor was free from overwhelming injustice.

Regarding the macromotive, the whole system evolved to ensure that derived economic value was halal (pure, permissible) which Muslims consider as a cornerstone of making justice to themselves and others. The derived wealth remained halal (existentially meaningful) as long as some of it was fed back into resourcing the system in accord with the normative 
standards of the period. The motive in the form [Value ${ }^{\text {Halal }}$ ] was a dynamic force, as its meaning depended on the character and extent of legitimizing institutions erected to protect it. Consequently, a weakly legitimized self-interest based attempt by a party (for example, monopolization of trade by a ruler) could cause irreversible bifurcations in the system.

\section{The (Pre)Colonial Period}

As the global scale of trade along the Silk Road gradually declined from the 17 th century due to the growth of alternative maritime routes, the established institutions of justice gradually eroded. Internal competition for the control of shrinking trade resources became fierce. The three states (i.e. Bukhara, Khiva and Kokand) of the region vied for dominance leading to politico-economic fragmentation, frequent wars, destruction and poverty. By the 1800 s, these khanates became extremely poor (see Budrin memoirs (1871) [1820]). Increased oppression, corruption, and elitism reflected in privilege-based land ownership systems and more than ninety types of arbitrary taxes, duties, and forced labor (Juvonmardiev 1965) blunted the impact of ongoing investment in trade infrastructure (Adle, Habib, and Baipakov 2003). As the khans, based on the adaptation of the Mongol system Yassa, claimed absolute authority over most economic decisions, the general feeling of injustice has increased (Orzibekov 2006). There emerged a need for a new base for bozor revitalization.

Ironically, the imperial ambitions of Czar's Russia granted a new bedrock for the bozor's further evolution. Trade essentially shifted from an East-West (i.e. China to Europe) axis to a NorthSouth (i.e. Russia-India) one. Trade with Russia was booming by the mid-18th century (Eversmann 1823; Muhammadjonov and Nematov 1957). It involved the export of cotton, silk, yarn, wool, fur, cashmere, indigo, locally made fabrics, handicrafts, druid fruit and horses from the region, while imports included various metals, gold, industrial products including factory made fabrics, leather, and arms (Eversmann 1823).

The bozor marketing system was rebuilt following a similar path, but it involved a shift of resources to build, develop, and protect the trade routes with Russia. Bukhara traders were actively establishing safe routes to local Russian markets via Caspian Sea, Astrakhan, and Orenburg, while the role of bozor in Tashkent had grown substantially, due to the city's strategic location and the growing Russian population. The colonial governors (Tashkent) as well as the local khans (Kokand) and emirs (Bukhara) were in the business of building new bozors and expanding existing ones (Madrahimov 2009). Moreover, by this age the bozor had turned into a way of life for Uzbeks. Eversmann (1823) observed that trade was thoroughly integrated into the urban life in Central Asia as he estimated that a third of Bukhara city was occupied by bozor, where to his surprise, unlike typical open space markets, these markets were indistinguishable from streets and many traders and their families lived in quarters attached to shops. A Russian economist, Massalskiy (1913), observed that Tashkent's Eskishahar bozor was the busiest and noisiest place of the city which had 4500 trading houses including caravanserais, crafts shops, choyhonas (tea houses), and eateries. Figure 3 shows a typical trading space (i.e. do'kon) in a bozor.

Several general observations can be made regarding the macro processes in this period, as the pertained to goods. Whether the derived value was just now depended on the combination of colonial and religious legitimation. The colonial regulative influence was dominant and its impact significant (reflected in the abolition of slave trade, and also the partial liberalization of "vices" such as gambling, prostitution, and alcohol consumption). In addition, religious legitimation included the institutions of sadaqah (daily charity), zakat (the annual charity of $2.5 \%$ from tradeable assets directly paid to the poor), hashar (communal support) and waqf (charitable endowments). These institutions completed the loop of the bozor marketing system enabling the generation of legitimized value (McChesney 2014; Pianciola and Sartori 2007). In addition, the colonial/religious imperative ensured that trade remained open for mass participation, while religious courts (qadi), muhtasib and boj offices locally regulated the system. However, the colonial bozor marketing system suffered inherent inconsistency as local interests collided with the colonial policy.

The bozor increasingly transformed into a closed system as the extent of insulation from global markets increased. It became a rudimentary supplier of natural resources to the Czarist economy. The technological innovations of the industrial age, except the Trans-Caspian railroad system and some cotton processing factories in the Russian quarter of Tashkent, failed to penetrate the local economy. Much of indigenous technology remained primitive. These issues gave rise to the movement of Jadidism (a reformist movement among wealthy intellectuals) who felt that the old politico-economic system must be replaced with a new progressive establishment, since the wealth divide between the poor and the rich was appalling (Uzoqov and Kholboev 1993).

\section{The Soviet Period}

The Soviet period was characterized by an unexpected revival of bozor. Despite becoming isolated from international markets, the system continued to exist by drawing on yet another resource, that is, the USSR's state sector (Grossman 1977). The Soviets promised work, land, and free education for everyone (i.e. ultimate distributive justice), hence, the majority of Uzbek intelligentsia including Jadids initially supported the Red Revolution and collaborated with the Bolsheviks (Pianciola and Sartori 2007). The Soviet economic policy was driven by a goal of moneyless state distribution, which in practice led to futile attempts to abolish private property and concentrate productive/commercial capital under the state control. In fact, in Uzbekistan this policy resulted in an undeclared war against the orthodox system of bozor (Najmiddinov 2014). As private wealth was forcibly shifted to the public domain through the Soviet economic reforms (e.g. collectivization, kolkhozification, and state requisition), another bedrock for the bozor 


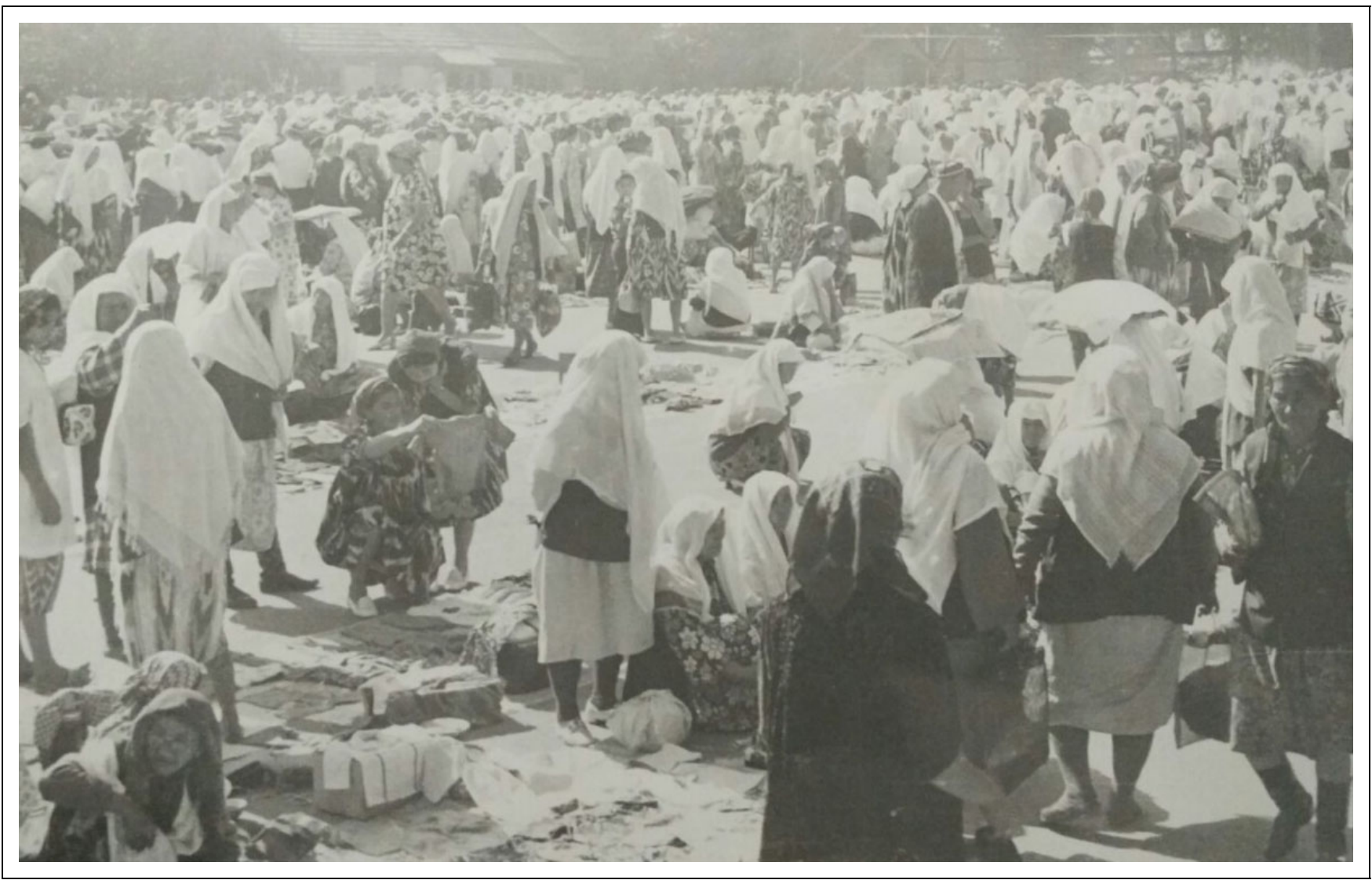

Figure 5. The white scarves of Andijan bozor in the mid-1980s (Source: an informant's personal photo collection).

marketing system was created. As the elderly informants indicated, a significant loss of wealth for the majority created an unspoken but commonly shared logic hidden behind the façade of mainstream socialist rhetoric: the state now owes much to people. The people attempted to recover what was rightfully theirs by diverting state resources to the private sector (i.e. reversing the private to public shift). This continued even at the times of relative abundance, post 1970s, which gave rise to the second economy (Grossman 1977; Mars and Altman 1986). Different markets allowing varying levels of private activity proliferated. Katsenelinboigen (1977) called these markets "coloured," as his classification comprised legal markets coded as red (e.g. the state retail system), white (e.g. kolkhoz markets), and pink (commission shops). Semi-legal markets were coded as grey (e.g. rental accommodation, private tuition), and illegal markets were coded as brown and black. In Uzbekistan, the second economy was in the form of bozor which entailed both direct and indirect involvement of most population including the higher echelons of the communist elite (Mars and Altman 1983, 1986). Most bozors were renamed to Kolkhoz Bozor (Collective Farm Market) enabling the inflow of state funding, as this was the only legal trade institution (classified as the white market) that allowed mass participation (Katsenelinboigen 1977). Thus, kolkhoz bozor became a façade for the revived bozor marketing system which supported culturally entangled trade - legal and illegal, open and under-counter, licensed and unlicensed - which included the assortments of food, clothing, precious jewelry, electronics, furniture, various imported goods, diverted army supplies, alcohol and drugs, rental accommodation, repair services, entertainment, to'y (i. e. cultural event) supplies, education and tutoring, and the mardikor market (day-laboring) (Figure 4).

The attenuating mechanisms were reflected in the Soviet establishment's constant ideological opposition to bozor. Specifically, traders were portrayed in popular culture as speculators, while ispolkoms (a local executive authority) and bozor committees regulated prices through setting upper limits (Katsenelinboigen 1977). OBKHSS (the economic police) made sure that traders stoked only licensed goods, thus limiting the scope of assortments on offer. An informant recalls a peculiar scene from Andijan Bozor in mid-1980s, where a big crowd of women in similar local attire, wearing white scarves wavering like sails, moved about selling locally made crafts (a criminal offence which could have been interpreted as sabotaging the Soviet economy) (Figure 5). The women used scarves to hide (unlicensed) goods, and when required, as a camouflage to vanish among the bozor crowd eluding a likely raid by militsiya (the Soviet police). Such evidence attests to people's resourcefulness in attempting to restore justice by tacitly claiming their perceived right to trade for private gain.

Against the backdrop of Soviet's guaranteed universal provisioning, the bozor marketing system turned into the 
technology of supplementary luxury provisioning (value beyond necessity) through catering for unaccounted heterogeneity. Paradoxically, the Soviet edifice (the state economy, reforms, formal communist rhetoric, market controls) was the essential foundation for perpetuating the bozor marketing system in its unique form. This edifice gave rise to the uniquely meaningful justice macromotive, the right for personal wealth over state provisioning, among supposedly Sovietized (i.e. collectivized) Uzbeks. Although formally disapproved, this type of economic value, which supplemented Soviet standard provisioning, became highly valued in informal cultural settings.

\section{The Independence Period}

The new reality of independence in 1991 has brought a renewed hope for the resurgence of the bozor as an integral part of the gradual shift toward market economy. The reverse public-to-private shift of resources has now occurred. The partial privatization of state assets, the reestablishment of private property rights, and the mass distribution of small farming lots to farm workers gave the system a new impetus for growth. Mass participation has become a real possibility; individual actors became free to sell and buy goods of their choice subject to the local regulations. The rise of shuttle trading partially exposed the system to the outside world. This period is characterized by the gradual development of legally established pathways of transforming public assets into private ones, although the process was far from perfect and was mediated by the government with a heavy hand. However, a quarter century of independent development failed to take the bozor marketing system beyond its subsistence provisioning status. There might be several reasons for this. First, representing the character of the official discourse about the bozor, the Soviet term Kolkhoz Bozor was simply replaced by Dehqon Bozor (i.e. farmers' market) which in practice severely limited the scope of its operations. Second, the state was reluctant to relax its tight grip over the economy. Although individual bozors were transformed into shareholding societies, the local hokimiyats (governing offices) controlled the majority of shares without exception, which gave the government absolute power over all key decisions, opening the door for corruption in many instances. Third, Uzbekistan pursued the strategy of import substitution and protectionism, while establishing a very complicated system of tax. Tax exemption and subsidies effectively barred the bozor marketing system from capitalizing on international trade and competitive markets. Fourth, the only "resources" that could potentially fuel the system were the local industry, the agricultural sector and shuttle trading. However, these resources did not materialize due to inadequate technological development (Hoshimov 2017), limited reforms in agriculture, excessive control over agricultural production and export, restricted access to foreign/local currency, and the vast bureaucratic apparatus of the government. Fifth, the bozor marketing system has become an arena of arbitrary administrative intrusion which should have supposedly worked as attenuating mechanisms.

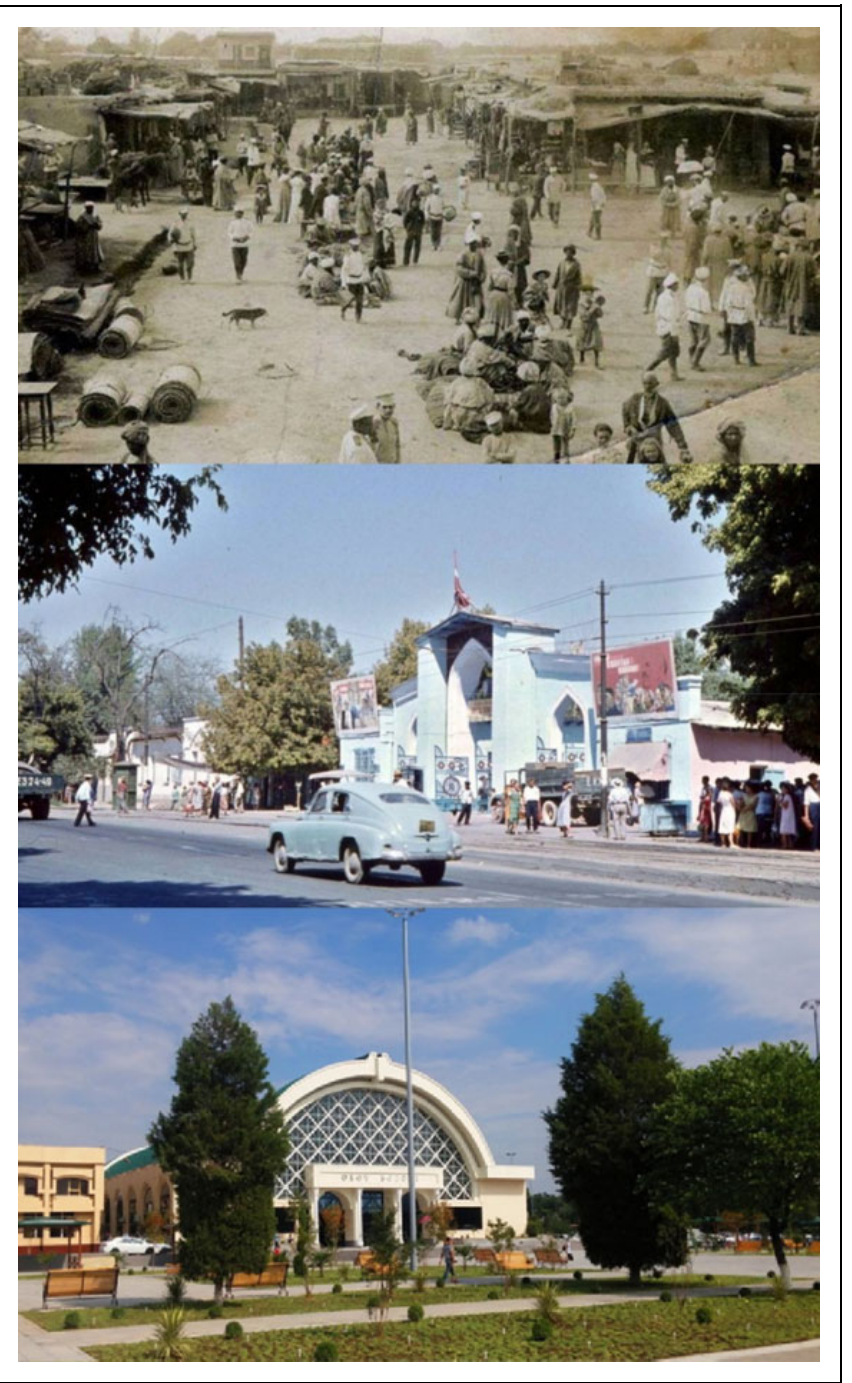

Figure 6. Oloy bozor during the colonial era (top), the Soviet period (middle), and after the 2017 reconstruction (bottom). (Source: Open access; accessed at www.mytashkent.uz).

An informant noted that the authorities set upper price limits for some food items (e.g. meat, oil), although traders circumvent such limits using various tricks to charge higher prices. Finally, more than anything else, the Soviet institutional legacy of covertly diverting state assets to the second economy did not disappear, rather it took a new character. The level of corruption has become unprecedented at all ranks. This corruption most often appears in form of bribery and the theft of assets from the public sector. Paradoxically, "blind" privatization cannibalized its own foundation (i.e. the generation and maintenance of the system as the public good).

The prominence of this matter is reflected in the recent decree by Uzbekistan's newly elected president's office that approved the program of Reconstruction of Dehqon Bozors in 2017-2019 and Creating Modern Trade Complexes (Uzbekistan National News Agency 2017). As it has been declared, the program is based on the review of 328 bozors across the 


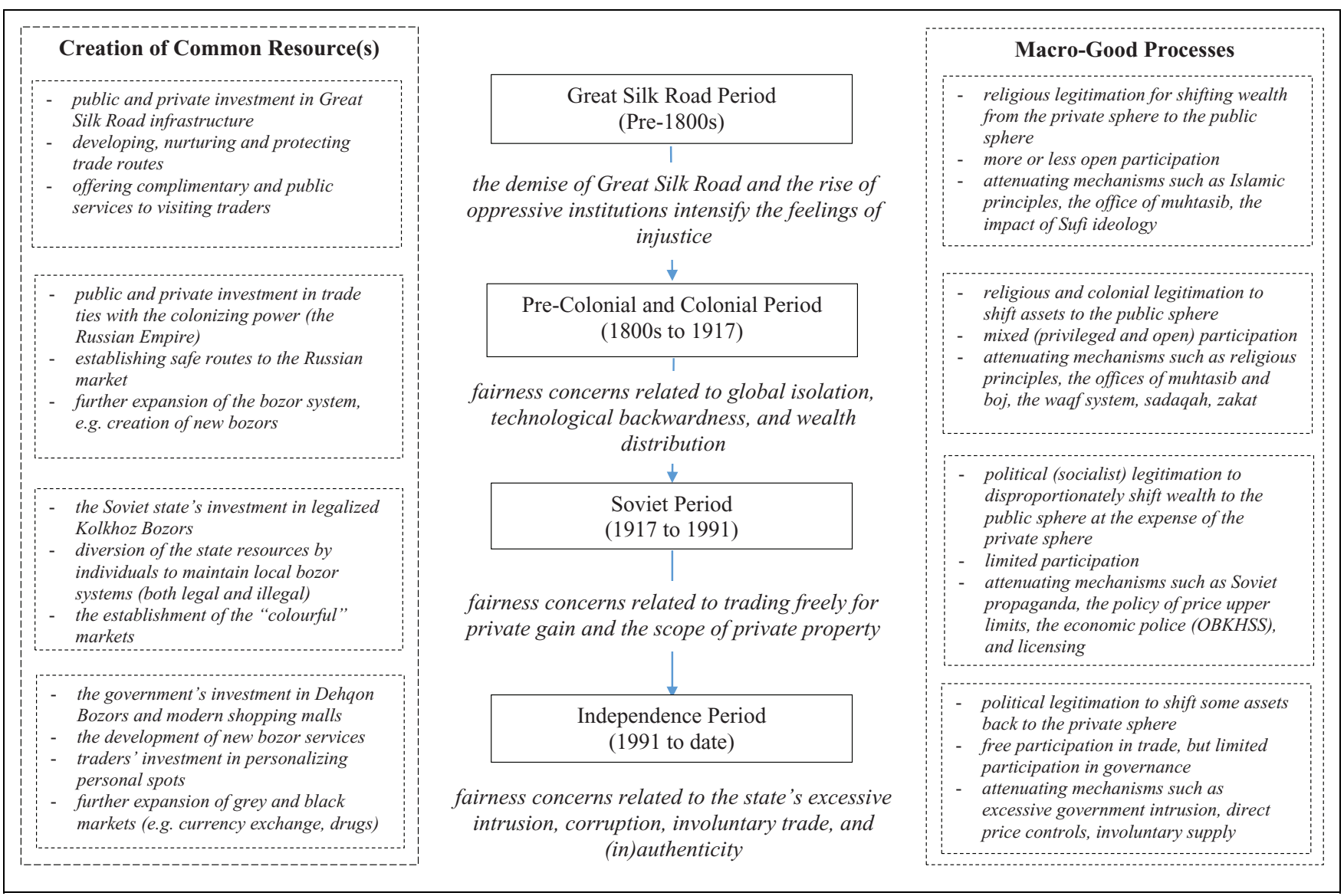

Figure 7. The evolution of the Uzbek Bozor Marketing System.

country that finds most of them to be in dissatisfactory condition along several criteria: design, convenience, structural and fire safety, sanitary conditions, food safety, parking availability, and the means of communication. It appears that the private sector has failed to automatically correct these issues. The program envisions spending 746 billion so'm (USD 178.6 million) from public resources to fully reconstruct most bozors (Figure 6). Each of the new complexes, depending on their size, will include a food safety laboratory, numerous weighing stations (for farmers), specialized banking branches (e.g. Agrobank), tax offices, cash and payment terminals, appropriate parking services, and warehouses. The investment in the marketing system as the public good is impressive, and it engenders yet renewed fairness-related reactions among stakeholders.

A trader explained that most traders wonder about whether they would receive a fair reimbursement for their previous investments in shops and other structures and if they could personalize their trading spot as they used to do previously. Another informant agreed that the new arrangement looks clean, tidy and well organized, however, would it not make bozors look bland and insipid? A consumer who is regular to a local bozor commented that supermarkets look "soulless", while a bit chaotic haggling over price with various small traders felt more real and authentic.

\section{Summary: The Bozor Marketing System as a Macro Public Good}

This case shows the resilience of the bozor marketing system in the backdrop of complex socio-historical and political shifts in the formulation of common resources as well as the emergent variations of the justice macromotive which influenced the system's common (dis)benefits through activating eccentric public-private asset transitions, contributory participation and attenuating processes. Figure 7 summarizes the main insights of the illustrative case. The Uzbek Bozor Marketing System in the current form bears the deep marks of its turbulent institutional evolution. This marketing system did not arise as a hodge-podge collection of traders and their micro-behavioral activities. Rather, various actors (e.g. government, local authorities, political groups, citizens, traders and consumers), guided by their perceptions of composite value, continually attempted to purposefully influence the bozors formation, structure, governance and evolutionary progress. Above all, different forces competed and cooperated in constructing, maintaining and improving common resources to enable the growth of the system. Although the outcomes were not always as expected, some degree of collective action was consistently required to improve the system's existence. The system was continually calibrated through changes initiated by governments, interest 
groups and market actors. These changes were in the form of public-private transitions, contributory participation, and corrections to attenuating mechanisms.

\section{Conclusions, Discussion and Suggestions}

\section{Alternative Marketing-Systems Understanding}

The Marketing-Systems-as-a-Public-Good offers an alternative understanding of marketing systems: it combines the rational view (Layton 2015), the normative perspective (Laczniak and Murphy 2008), and the symbolic approach (Kadirov and Varey 2011). Change is meaningful within a marketing system: the public good processes determine the specific meaning of composite value (i.e. the value augmented with a macromotive) for marketing system actors. As meaning is crystallized through regulative and normative corrections, an array of potential composite value is enabled. Various groups adopt the different variants of potential value, contest their meaning, and initiate further cycles of public-good processes.

\section{Internally "Understandable" Corrections}

Different marketing systems with peculiar forms are observed globally (Layton 2007). The unique processes of the Uzbek Bozor Marketing System are the manifestation of collective action guided by specific institutional meanings of composite value. Distinct structures and forms are created, maintained and altered not just because existing arrangements do not meet direct consumption needs but also when they do not fulfill justice expectations. Perceived injustice may lead to the redefinition of common resource(s), public-private good shifts, and distinctive contributions into marketing-system governance and attenuating market mechanisms.

In relation to the question posed at the beginning of this article, one can draw many insights about the ways of introducing corrective changes in marketing systems. An externally imposed correction would not be successful if such changes are not picked up by an endogenous cascade of alterations that are internally meaningful against the backdrop of the system's long-term development path. For instance, a desired shift could be formulated in terms of its impact on the specific perceptions of fairness. To create a cumulative effect based on the voluntary uptake of a proposed change within the marketing system, the corrective intervention can be framed and promoted using the justice discourse. In this process, the specific mechanisms reviewed in this article can be used. For example, there is a possibility of the Uzbek Bozor Marketing System linking to China's USD 900 billion Belt and Road Action Plan that aims to re-create the Silk Road (World Economic Forum 2017). Hence, the system can potentially become a regional logistics services hub, the vision that would require more purposeful effort than rebuilding isolated structures.

\section{Existential Value of Marketing Systems}

The Marketing Systems-as-the-Public-Good framework highlights the existential aspect of marketing systems: market actors derive composite value through participating and constructing meaningful action fields (i.e. marketing systems) in addition to obtaining value from the direct output of these marketing systems. The existential aspect of marketing systems is at the heart of strategic action fields theory and the MAS framework (Fligstein and McAdam 2012; Layton 2015). Meaningfulness and morality, expressed in the questions like "what is good/just life?" and distinctive answers to these fundamental questions underscore the formation of action fields (Fligstein and McAdam 2012), including the formation of marketing systems (Layton 2015). A development initiative that uncritically accepts the institutional logic expressed as "consumption of goods is the only route to happiness" (Kilbourne, McDonagh, and Prothero 1997) might be fundamentally flawed, as the abundance of goods may not be satisfying if marketing systems are not conducive to the internally accepted standards of justice.

The existential importance of marketing systems for meaningful human existence, is illustrated in the context of wars. From the macromarketing perspective, wars are seen as marketing-system stripping "experiments" through which a dominant power cripples the life support mechanisms of communities seen as "enemy" (Shultz 2016; Shultz et al. 2005). Shultz and his colleagues' (Shultz 2016, 2017; Shultz et al. $2005)$ research in war-ravaged areas indicates that the obliteration of marketing systems causes feelings of misery, distress, and meaninglessness. They show that in such circumstances people attempt, more than anything else, to re-build structures approximating previous marketing systems. Although the supply of vital goods is quickly re-established, the unique value and meaningfulness of ruined marketing systems is what people first attempt to restore. Perhaps, the macromotive for justice in these circumstances would motivate people to bring back those unique market structures which they perceive to be fair.

The progress toward just marketing systems presumes orderly, effortless, riskless, and dignifying participation in value creation practices, while bringing out the best in human beings (Ostrom 2005). Not only automatic resource acquisition, but also constructing fair and equitable provisioning systems that facilitate the sustainable utilization of resources should be the aim (Ferrell and Ferrell 2008). The value augmented with justice represents the desire to participate in meaningful, beneficial, and fair value-creating interactions (Varey, Sörhammar, and Kadirov 2015). Such a macro-turn in understanding actors' motives offers a different insight about marketing systems: the "output" of marketing systems is not only goods assortments but also a macro-service, which can be characterized as the provision of justice, meaningfulness, sustainable commerce opportunities, and inclusive participation in value creation (Varey 2013; Varey, Sörhammar, and Kadirov 2015). This includes the nourishment of capabilities to build lives people have reason to value (Sen 1999), social skill 
(Fligstein and McAdam 2012), and balanced opportunities to all citizens for pursuing individual and communal ends (Acemoglu and Robinson 2012; Daly and Cobb 1994).

\section{Limitations and Future Research}

The proposed framework barely scratches the surface of the problem of change in marketing systems. Conceptually, the framework can potentially explain, from the marketing-systems-as-a-public-good perspective, why both collectivist/ socialist and privatization-based reforms might fail to deliver justice. Moreover, future research is required to provide detailed elaboration on the concepts, relationships, and processes included in the framework. Specifically, what are the precise mechanisms that govern the construction of "private' (e.g. wealth, space, identity) spaces within marketing systems and its relation to "public"? What are the other types of macromotives that might structure value creation processes? Also, this research can be productively extended to investigate typologies of actors and their practices in constructing different variations of composite value, the ways these actors interact in shaping marketing-systems as the public good, the paths justice-based or other macromotive-based discourses take in structuring the course of marketing system evolution, and specific structures of attenuating mechanisms that provide macromotive-based calibration.

\section{Declaration of Conflicting Interests}

The author(s) declared no potential conflicts of interest with respect to the research, authorship, and/or publication of this article.

\section{Funding}

The author(s) received no financial support for the research, authorship, and/or publication of this article.

\section{ORCID iD}

Djavlonbek Kadirov (D) http://orcid.org/0000-0001-7618-6903

\section{References}

Acemoglu, Daron and James A. Robinson (2012), Why Nations Fail: The Origins of Power, Prosperity, and Poverty. New York: Crown Publishers.

Adle, Chahryar, Irfan Habib, and Karl M. Baipakov (2003), History of Civilizations of Central Asia. Volume IV: Development in Contrast: From the Sixteenth to the Mid-Nineteenth Century. Paris: UNESCO Publishing.

Araujo, Luis (2007), "Markets, Market-Making and Marketing," Marketing Theory, 7 (3), 211-26.

Bateson, Gregory (1991), A Sacred Unity: Further Steps to an Ecology of Mind. New York: Cornelia and Michael Bessie Book.

Beckwith, Christopher I. (2009). Empires of the Silk Road: A History of Central Eurasia from the Bronze Age to the Present. Princeton, NJ: Princeton University Press.

Bergson, Abram (1938), "A Reformulation of Certain Aspects of Welfare Economics," Quarterly Journal of Economics, 52 (February), 310-34.
Blau, Peter M. (1964), Exchange and Power in Social Life. New York: Wiley.

Budrin, Vasiliy ((1871) [1820]). Русские в Бухаре в 1820 г.: Записки очевидца (Russians in Bukhara in 1820: The Notes of an Eyewitness). Orenburg, Russia: The Reference Book of Orenburg Region.

Calabresi, Guido and Philip Bobbitt (1978), Tragic Choices: The Conflicts Society Confronts in the Allocation of Tragically Scarce Resources. New York: WW Norton \& Co.

Cornes, Richard and Todd Sandler (1996), The Theory of Externalities, Public Goods, and Club Goods. Cambridge, UK: Cambridge University Press.

Crozet, Yves and Hector G. Lopez-Ruiz (2013), "Macromotives and Microbehaviors: Climate Change Constraints and Passenger Mobility Scenarios for France," Transport Policy, 29 (C), 294-302.

Daly, Herman E. and John B. Cobb (1994), For the Common Good: Redirecting the Economy toward Community, the Environment, and a Sustainable Future. Boston, MA: Beacon Press.

Duan, Naibin, Bai Yang, Sun Honghe, Wang Nan, Ma Yumin, Li Mingjun, Wang Xin, Jiao Chen, Legall Noah, Mao Linyong, Wan Sibao, Wang Kun, He Tianming, Feng Shouqian, Zhang Zongying, Mao Zhiquan, Shen Xiang, Chen Xiaoliu, Jiang Yuanmao, Wu Shujing, Yin Chengmiao, Ge Shunfeng, Yang Long, Jiang Shenghui, Xu Haifeng, Liu Jingxuan, Wang Deyun, Qu Changzhi, Wang Yicheng, Zuo Weifang, Xiang Li, Liu Chang, Zhang Daoyuan, Gao Yuan, Xu Yimin, Xu Kenong, Chao Thomas, Fazio Gennaro, Shu Huairui, Zhong Gan-Yuan, Cheng Lailiang, Fei Zhangjun, and Chen Xuesen (2017), "Genome Re-Sequencing Reveals the History of Apple and Supports a Two-Stage Model for Fruit Enlargement," Nature Communications, 8 (1), (accessed October 18, 2017), [available at https://www.nature.com/articles/ s41467-017-00336-7].

Duffy, Sarah, Roger Layton, and Larry Dwyer (2017), "When the Commons call "Enough", Does Marketing Have an Answer?" Journal of Macromarketing, 37 (3), 268-85.

Eversmann, Eduard (1823), “Account of Bucharia," In Nazarov, Filipp, Pavel Luk'ianovich Iakovlev, and Nikolaĭ Nikolaevich Murav'ev. Russian Missions Into the Interior of Asia. London: Printed for R. Phillips, pp. 11-61.

Ferrell, O. C. and Linda Ferrell (2008) "A Macromarketing Ethics Framework: Stakeholder Orientation and Distributive Justice," Journal of Macromarketing, 28 (1), 24-32.

Flikr, "Chorsu Bazaar, Tashkent, Uzbekistan", https://www.flickr.com/ photos/10186213@N07/20587731208/ (accessed October 18, 2017).

Fisk, George (1974), Marketing and the Ecological Crisis. New York: Harper and Row.

Fisk, George (1967), Marketing Systems: An Introductory Analysis. New York: Harper and Row.

Fisk, George (1997), "Questioning Eschatological Questions about Marketing Apocalypse Conditional," European Journal of Marketing, 31 (9/10), 720-29.

Fligstein, Neil and Doug McAdam (2012), A Theory of Fields. Oxford, UK: Oxford University Press.

Foldvary, Fred E. (1994), Public Goods and Private Communities. Brookfield, VT: Edward Elgar Publishing Company. 
Furnham, Adrian (2003), "Belief in a Just World: Research Progress over the Past Decade," Personality and Individual Differences, 34 (5), 795-817.

Galbraith, John K. (1958), The Affluent Society. Harmondsworth, Middlesex: Penguin Books.

Giesler, Markus (2008), "Conflict and Compromise: Drama in Marketplace Evolution," Journal of Consumer Research, 34 (April), 739-53.

Gilles, Robert F. and Dimitrios Diamantaras (2005), "New Classical Economics: Towards a New Paradigm for Economics," Division of Labor and Transaction Costs, 1(1), 35-56.

Grossman, Gregory (1977), "The Second Economy of the USSR," Problems of Communism, 26 (5), 25-40.

Haase, Michaela, Ingrid Becker, and Doreén Pick (2017), “Alternative Economies as Marketing Systems? The Role of Value Creation and the Criticism of Economic Growth," Journal of Macromarketing, (accessed October 18, 2017), [available at http://jmk.sagepub. com].

Haksöz, Çağrı, Sridhar Seshadri, and Ananth V. Iyer, eds. (2011), Managing Supply Chains on the Silk Road: Strategy, Performance, and Risk. Boca Raton, FL: CRC Press.

Hardin, Garrett (1968), "The Tragedy of the Commons," Science, 162 (3859), 1243-48.

Holmes, John G. (1981), "The Exchange Process in Close Relationships: Microbehavior and Macromotives," in The Justice Motive in Social Behavior, M. J. Lerner and S. C. Lerner, eds. New York: Plenum, 261-84.

Homans, George (1961), Social Behavior: Its Elementary Forms. New York: Harcourt Brace Jovanovich.

Hoshimov, Behzod (2017), Что может производить Узбекистан, чтобы развивать экономику? (accessed October 27, 2017), [available at http://kommersant.uz/kejs/chto-mozhet-proizvodit].

Huff, Aimee Dinnin, Michelle Barnhart, Brandon McAlexander, and Jim McAlexander (2017), "Addressing the Wicked Problem of American Gun Violence: Consumer Interest Groups as Macrosocial Marketers," Journal of Macromarketing, 37 (4), 393-408.

Humphreys, Ashlee (2010), "Megamarketing: The Creation of Markets as a Social Process," Journal of Marketing, 74 (2), 1-19.

Jagadale, Sujit Raghunathrao, Djavlonbek Kadirov, and Debojyoti Chakraborty (2017), "Tackling the Subaltern Quandary: Marketing Systems of Dignity," Journal of Macromarketing, (accessed December 3, 2017), [available at http://jmk.sagepub.com].

Juvonmardiev, Abdullajon (1965), XVI-XIX Asrlarda Farg'onada ErSuv Masalalariga Doir. Toshkent: O’zbekiston SSR Fan Nashriyoti.

Kadirov, Djavlonbek (2011), "Macro-Systems Role of Marketing: Do We Trade Environment for Welfare?" Journal of Macromarketing, 31 (4), 359-75.

Kadirov, Djavlonbek and Richard J. Varey (2011), "Symbolism in Marketing Systems," Journal of Macromarketing, 31 (2), 160-71.

Kadirov, Djavlonbek, Richard J. Varey, and Sally Wolfenden (2016), "Investigating Chrematistics in Marketing Systems: A Research Framework," Journal of Macromarketing, 36 (1), 54-67.

Kalberg, Stephen (1980), "Max Weber's Types of Rationality: Cornerstones for the Analysis of Rationalization Processes in History," American Journal of Sociology, 85 (5), 1145-79.
Kapp, William K. (1970), "Environmental Disruption: General Issues and Methodological Problems," Social Science Information, 9 (4), 15-32.

Kapp, William K. (1978), The Social Costs of Business Enterprise. Nottingham, UK: Russell Press Ltd.

Katsenelinboigen, Aron (1977), "Coloured Markets in the Soviet Union,” Soviet Studies, 29 (1), 62-85.

Kaul, Inge, Isabelle Grunberg, and Marc A. Stern, eds. (1999), Global Public Goods: International Cooperation in the 21st Century. Oxford, UK: Oxford University Press.

Kennedy, Ann-Marie (2017), "Macro-Social Marketing Research: Philosophy, Methodology and Methods," Journal of Macromarketing, 37 (4), 347-55.

Khvandmir, Muhammad ((1979) [1558]). The Makarim Al-Akhlaq. Cambridge, UK: EJB Gibb Memorial Trust.

Kilbourne, William, Pierre McDonagh, and Andrea Prothero (1997), "Sustainable Consumption and the Quality of Life: A Macromarketing Challenge to the Dominant Social Paradigm," Journal of Macromarketing, 17 (1), 4-24.

Kjellberg, Hans and Claes-Fredrik Helgesson (2007), "On the Nature of Markets and Their Practices," Marketing Theory, 7 (2), 137-62.

Klein, Thomas A. (2008), "Assessing Distributive Justice in Marketing: A Benefit-Cost Approach," Journal of Macromarketing, 28 (1), 33-43.

Kotchen, M. J. (2005), "Impure Public Goods and the Comparative Statics of Environmentally Friendly Consumption," Journal of Environmental Economics and Management, 49 (2), 281-300.

Kozinets, Robert V. and Jay Handelman (2004), "Adversaries of Consumption: Consumer Movements, Activism, and Ideology," Journal of Consumer Research, 31 (December), 691-704.

Kuzmina, Elena E. (2008), The Prehistory of the Silk Road. Philadelphia, PA: University of Pennsylvania Press.

Laczniak, Gene R. and Patrick E. Murphy (2008), "Distributive Justice: Pressing Questions, Emerging Directions, and the Promise of Rawlsian Analysis," Journal of Macromarketing, 28 (1), 5-11.

Laczniak, Gene R. and Nicholas J. C. Santos (2011), "The Integrative Justice Model for Marketing to the Poor: An Extension of SD Logic to Distributive Justice and Macromarketing," Journal of Macromarketing, 31 (2), 135-47.

Layton, Roger A. (2007), "Marketing Systems - A Core Macromarketing Concept," Journal of Macromarketing, 27 (3), 227-42.

Layton, Roger A. (2009), On Economic Growth, Marketing Systems, and the Quality of Life," Journal of Macromarketing, 29 (4), 349-62.

Layton, Roger A. (2015), "Formation, Growth, and Adaptive Change in Marketing Systems," Journal of Macromarketing, 35 (3), 302-19.

Layton, Roger (2017), "The Systems Workshop: Open Questions in Marketing System Theory and Application," Macromarketing Conference 2017, Queenstown.

Layton, Roger and Sarah Duffy (2017), "Path Dependency and Beyond in Marketing Systems: Origins and Implications," Macromarketing Conference 2017, Quennstown.

Lerner, M. J. (1981), "The Justice Motive in Human Relations," in The Justice Motive in Social Behavior: Adapting to Times of 
Scarcity and Change, Melvin J. Lerner and Sally C. Lerner, eds. New York: Plenum Press, 11-35.

Lerner, Melvin J. (1977), "The Justice Motive: Some Hypotheses as to Its Origins and Forms," Journal of Personality, 45 (1), 1-52.

Lerner, Melvin J. (2003), "The Justice Motive: Where Social Psychologists Found It, How They Lost It, and Why They May not Find It Again," Personality and Social Psychology Review, 7 (4), 388-99.

Lerner, Melvin J. and Sally C. Lerner (1981), The Justice Motive in Social Behavior: Adapting to Times of Scarcity and Change. New York: Plenum Press

Lerner, Melvin J. and Dale T. Miller (1978), “Just World Research and The Attribution Process: Looking Back and Ahead," Psychological Bulletin, 85 (5), 1030-51.

Madrahimov, Z. S. (2009), Кўқон хонлиги божхоналари ва уларнинг фаолияти [Customs Service in the Khanate of Kokand and its Functions]. Namangan, Uzbekistan: Science Digest.

Mars, Gerald and Yochanan Altman (1986), "The Cultural Bases of Soviet Central Asia's Second Economy (Uzbekistan And Tajikistan)," Central Asian Survey, 5 (3/4), 195-204.

Mars, Gerald and Yochanan Altman (1983), "The Cultural Bases of Soviet Georgia's Second Economy,” Soviet Studies, 35 (4), 546-60.

Mas-Colell, Andreu, Michael D. Whinston, and Jerry R. Green (1995), Microeconomic Theory. New York: Oxford University Press.

Massalskiy, Vladislav Ivanovich (1913), Туркестанский край [The Region of Turkestan]. St Petersburg, Russia: A.F. Devrien Publishing.

Mazzola, Ugo ((1958) [1890]), "The Formation of the Prices of Public Goods," in Classics in the Theory of Public Finance, R. A. Musgrave and Alan T. Peacock, eds. UK: Palgrave Macmillan, 37-47.

McAdam, Doug (1996), "The Framing Function of Movement Tactics: Strategic Dramaturgy in the American Civil Rights Movement," in Comparative Perspectives on Social Movements: Political Opportunities, Mobilizing Structures, and Cultural Framings, Doug McAdam, John D. McCarthy, and Mayer N. Zald, eds. Cambridge Studies in Comparative Politics. Cambridge, MA: Cambridge University Press, 338-56.

McChesney, Robert D. (2014), Waqf in Central Asia: Four Hundred Years in the History of a Muslim Shrine, 1480-1889. Princeton, NJ: Princeton University Press.

Mittelstaedt, J. D., W. E. Kilbourne, and R. A. Mittelstaedt (2006), "Macromarketing as Agorology: Macromarketing Theory and the Study of the Agora," Journal of Macromarketing, 26 (2), 131-42.

Montada, Leo (2002), "Doing Justice to the Justice Motive," in The Justice Motive in Everyday Life, Michael Ross and Dale T. Miller, eds., 41-62. Cambridge, UK: Cambridge University Press.

Mottahedeh, Roy and Kristen Stilt (2003), "Public and Private as Viewed through the Work of the "Muhtasib,"' Social Research, 70 (3), 735-48.

Muhammadjonov, Abdulahad R. and T. Nematov (1957), Бухоро ва Хеванинг Россия билан Муносабатлари Тарихига Доир Баъзи Манбалар (Some Sources on the History of Relationships of Bukhara and Kheva with Russia). Tashkent: Uzbekistan SSR Science Academy.

Najmiddinov, Qodirjon (2014), "Namangan Bozorlari Tarixi," Unpublished thesis, Namangan.
Nenonen, Suvi, Hans Kjellberg, Jacqueline Pels, Lilliemay Cheung, Sara Lindeman, Cristina Mele, Laszlo Sajtos, and Kaj Storbacka (2014), "A New Perspective on Market Dynamics: Market Plasticity and the Stability-Fluidity Dialectics," Marketing Theory, 14 (3), 269-89.

Nielsen, Sarah K. (2015), "Support or Fairness? Differential Effects of Social Support and Organizational Justice on Work Outcomes," American Journal of Management, 15 (4), 26.

Orzibekov, Rahmonqul (2006), O‘zbek Adabiyoti Tarixi: XVII-XIX (I yarmi) asrlar (The History of Uzbek Literature (17-19th Centuries). Tashkent, Uzbekistan: Uzbekistan Writers Society's Literature Fund Publishing House.

Ostrom, Elinor (2005), Understanding Institutional Diversity. Princeton, NJ: Princeton University Press.

Ostrom, Elinor (2010), "Beyond Markets and States: Polycentric Governance of Complex Economic Systems," Transnational Corporations Review, 2 (2), 1-12.

Ostrom, Vincent and Elinor Ostrom (1977), "Public Goods and Public Choices," in Alternatives for Delivering Public Services: Toward Improved Performance, E. S. Savas, ed. Boulder, CO: Westview Press, 7-49.

Patsiaouras, Georgios, Michael Saren, and James A. Fitchett (2015), "The Marketplace of Life? An Exploratory Study of the Commercialization of Water Resources through the Lens of Macromarketing," Journal of Macromarketing, 35 (1), 23-35.

Pianciola, Niccolò and Paolo Sartori (2007), "Waqf in Turkestan: The Colonial Legacy and the Fate of an Islamic Institution in Early Soviet Central Asia, 1917-1924," Central Asian Survey, 26 (4), 475-98

Redmond, William H. (2013), "A Marketing Systems View of the US Housing Crisis," Journal of Macromarketing, 33 (2), 117-27.

Roth, Alvin E. (2008), "What Have We Learned From Market Design?” Economic Journal, 118 (527), 285-310.

Roth, Alvin E. (2007), "Repugnance as a Constraint on Markets," Journal of Economic Perspectives, 21 (3), 37-58.

Roth, Alvin E. (2013), "What have we learned from market design?" in Nir Vulkan, E. Roth Alvin, and Neeman Zvika (2013), eds. The Handbook of Market Design. Oxford, UK: Oxford University Press, pp. 7-50.

Samuelson, Paul A. (1954), "The Pure Theory of Public Expenditure," The Review of Economics and Statistics, 36 (4), 387-89.

Sax, Emil ((1958) [1924]), "The Valuation Theory of Taxation," in Classics in the Theory of Public Finance, R. A. Musgrave and Alan T. Peacock, eds. UK: Palgrave Macmillan, 177-89.

Scaraboto, Daiane and Eileen Fischer (2013), "Frustrated Fatshionistas: An Institutional Theory Perspective on Consumer Quests for Greater Choice in Mainstream Markets," Journal of Consumer Research, 39 (6), 1234-57.

Scott, W. Richard (2014). Institutions and Organizations: Ideas, Interests, and Identities. Thousand Oaks: CA: Sage.

Selznick, Philip (1969), Law, Society, and Industrial Justice. New York: Russell Sage Foundation.

Selznick, Philip (2011). Leadership in Administration: A Sociological Interpretation. New Orleans, LA: Quid Pro Books.

Sen, Amartya (1999), Development as Freedom. New York: Knopf. 
Sen, Amartya (2005), "Human Rights and Capabilities," Journal of Human Development, 6 (2), 151-66.

Sheth, Jagdish N. (1992), "Toward a Theory of Macromarketing," Canadian Journal of Administrative Sciences, 9 (2), 154-61.

Shultz, Clifford (2016), "Marketing an End to War: Constructive Engagement, Community Wellbeing, and Sustainable Peace," Markets, Globalization \& Development Review, 1 (2), 1-23.

Shultz, Clifford J. (2017), "Marketing-Systems Research in Devastated, Distressed and Recovering Economies: Reflections on Foci, Sites, Methods, Challenges and Opportunities," Macromarketing Conference 2017, Queenstown, New Zealand.

Shultz, Clifford J., T. J. Burkink, B. Grbac, and N. Renko (2005), "When Policies and Marketing Systems Explode: An Assessment of Food Marketing in the War- Ravaged Balkans and Implications for Recovery, Sustainable Peace, and Prosperity," Journal of Public Policy \& Marketing, 24 (1), 24-37.

Shultz, Clifford J. and Morris B. Holbrook (1999), "Marketing and the Tragedy of the Commons: A synthesis, Commentary, and Analysis for Action." Journal of Public Policy \& Marketing, 18 (2), 218-29.

Spector, Regine A. (2017), Order at the Bazaar: Power and Trade in Central Asia. Ithaka, NY: Cornell University Press.

Stiglitz, Joseph. E. (2014), "Tapping the Brakes: Are Less Active Markets Safer and Better for the Economy?" Atlanta, GA: Federal Reserve Bank of Atlanta 2014 Financial Markets Conference.

Uzbekistan National News Agency (2017), 2017-2019-Yillar Davrida Dehqon Bozorlarini Rekonstruksiya Qilish va Ularning Hududida Zamonaviy Savdo Majmualari Qurish Dasturini Tasdiqlash To'g'risida, (accessed December 7, 2017), [available at http:// www.uza.uz/uz/documents/davrida-dehqon-bozorlarini-rekonstruk siya-q-28-03-2017].

Uzoqov, Haydarali and Kholboev Sotimhon (1993) "Buxoro amirining oltinlari (The Wealth of Bukhara's Emir)." Hayot va Hisobot, 3-6 (1), 1-20.

Vann, John W. and Erdoğan Kumcu (1995), “Achieving Efficiency and Distributive Justice in Marketing Programs for Economic Development," Journal of Macromarketing, 15 (2), 5-22.

Varey, Richard J. (2013), "Marketing in the Flourishing Society Megatrend," Journal of Macromarketing, 33 (4), 354-68.

Varey, Richard J., David Sörhammar, and Djavlonbek Kadirov (2015), "The Phenomenon of Participating: From Apart to Win, to Playing a Part," Social Business, 5 (4), 343-59.

Vargo, Stephen L. and Melissa A. Akaka (2012), "Value Cocreation and Service Systems (Re)formation: A Service Ecosystems View," Service Science, 4 (3), 207-17.

Vargo, Stephen L. and Robert F. Lusch (2016), "Institutions and Axioms: An Extension and Update of Service-dominant Logic," Journal of the Academy of Marketing Science, 44 (1), 5-23.

Vargo, Stephen L., Kaisa Koskela-Huotari, Steve Baron, Bo Edvardsson, Javier Reynoso, and Maria Colurcio (2017), “A Systems Perspective on Markets-Toward a Research Agenda," Journal of Business Research (2017), (accessed January 16, 2018), [available at https:// doi.org/10.1016/j.jbusres.2017.03.011].

Vikas, Ram Manohar, Rohit Varman, and Russell W. Belk (2015), "Status, Caste, and Market in a Changing Indian Village," Journal of Consumer Research, 42 (3), 472-98.

Viti de Marco, Antonio de (1936), First Principles of Public Finance. New York: Harcourt, Brace, \& Co.

Vulkan, Nir, Alvin E. Roth, and Zvika Neeman, eds. (2013), The Handbook of Market Design. Oxford, UK: OUP Oxford.

Weber, Max ((2017) [1920]), Methodology of Social Sciences. New York, NY: Routledge.

Wicksell, Knut ((1958) [1896]), "A New Principle of Just Taxation," in Classics in the Theory of Public Finance, R. A. Musgrave and Alan T. Peacock, eds. UK: Palgrave Macmillan, 177-89.

Wikimedia Commons contributors, "File:25 Buhara po mestu (39). JPG," Wikimedia Commons, the free media repository, https://com mons.wikimedia.org/w/index.php?title=File:25_Buhara_po mestu_(39).JPG\&amp;oldid=214861062 (accessed Ocotber 18, 2017).

Williamson, Oliver E. (1985), The Economic Institutions of Capitalism. New York: Free Press.

World Economic Forum (2017), China's \$900 Billion New Silk Road. What You Need to Know. Ed. Anna Bruce-Lockhart, (accessed 7 December 2017), [available at https://www.weforum.org/agenda/ 2017/06/china-new-silk-road-explainer/].

Yang, Xiaokai (2003), Economic Development and the Division of Labor. Malden, MA: Blackwell Publishing.

Zanca, Russell (2010), Life in a Muslim Uzbek Village: Cotton Farming After Communism CSCA. Belmont, CA: Wadsworth Cengage Learning.

\section{Author Biography}

Djavlonbek Kadirov (PhD, University of Waikato) is a marketing lecturer at the School of Marketing and International Business, Victoria University of Wellington, New Zealand. Djavlonbek's research interests include marketing systems theory, symbolism in marketing systems, sustainable marketing, and marketing morality. His research has appeared in journals such as the Journal of Macromarketing, Journal of Marketing Management, Journal of Business Research, Journal of Brand Management, Consumption Markets \& Culture, and Journal of Customer Behaviour. Djavlonbek (along with Richard Varey and Ben Wooliscroft) is the winner of the George Fisk Award for the Best Conference Paper at the 2013 Macromarketing Conference. 